
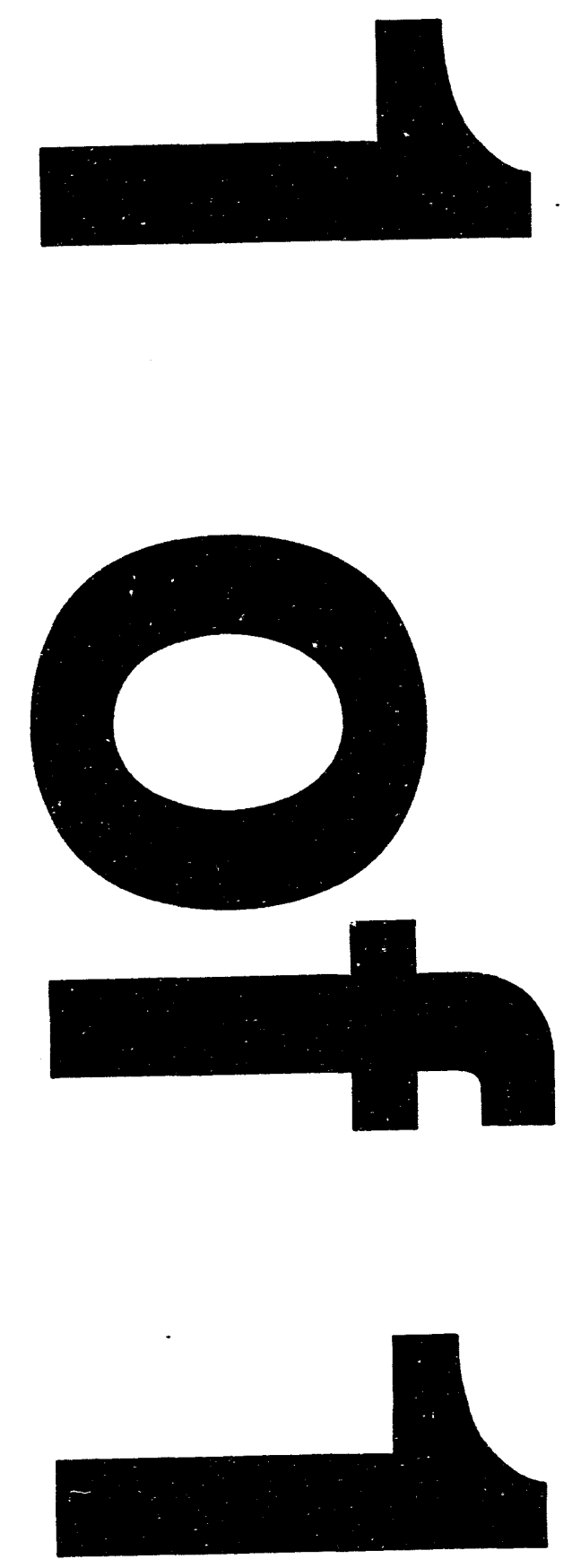


\title{
PILOT-SCALE BENZENE STRIPPING COLUMN TESTING: REVIEW OF TEST DATA AND APPLICATION TO THE ITP COLUMNS (U)
}

by

\author{
G. K. Georgeton
}

Westinghouse Savannah River Company

Savannah River Site

Aiken, South Carolina 29808

\section{G. A. Taylor}

T.P. Gaughan

This paper was prepared in connection with work done under the above contract number with the U.S. Department of Energy. By acceptance of this paper, the publisher and/or recipient acknowledges the U. S. Government's right to retain a nonexclusive, royalty-frcie license in and to any copyright covering this paper, along with the right to reproduce and to aut iorize others to reproduce all or part of the copyrighted paper.

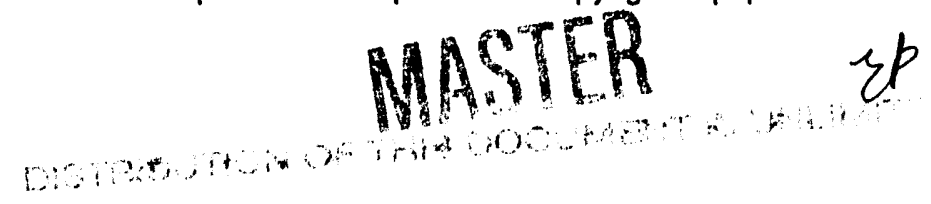




\section{DISCLAIMER}

This reporn was prepared as an account of work sponsored by an agency of the United States Government. Neither the United States Government nor any agency thereof, nor any of their employees, makes any warranty, express or implied, or assumes any legal liability or responsibility for the accuracy, completeness, or usefulness of any information, apparatus, product, or process disclosed, or represents that its use would not infringe privately owned rights. Reference herein to any specific commercial product, process, or service by trade name, trademark, manufacturer, or otherwise does not necessarily constitute or imply its endorsement, recommendation, or favoring by the United States Government or any agency thereof. The views and opinions of authors expressed berein do not necessarily state or reflect those of the United States Government or any agency thereof.

This repor has been reproduced directly from the best available copy.

Available to DOE and DOE contractors from the Office of Scientific and Technical Information, P. O. Box 62, Oak Ridge. TN 37831; prices available from (615) $576-8401$.

Available to the public from the National Technical Information Service, U. S. Deparment of Commerce, S285 Port Royal Rd., Springfield, VA 22161 
HIGH LEVEL WASTE ENGINEERING

TANK FARM STUDIES SECTION

PILOT SCALE BENZENE STRIPPING COLUMN TESTING:

REVIEW OF TEST DATA AND APPLICATION TO

THE ITP COLUMNS

B Y

G. K. GEORGETON

T. P. GAUGHAN

G. A. TAYLOR

ISSUED: 9/10/93
WSRC-TR-93-468

REVISION: 0

KEYWORDS: High Level

Waste Engineering,

Structured Packing, Foaming,

Tributyl Phosphate

\section{RETENTION:}

PERMANENT

CLASSIFICATION:

GNCLASSIFIED

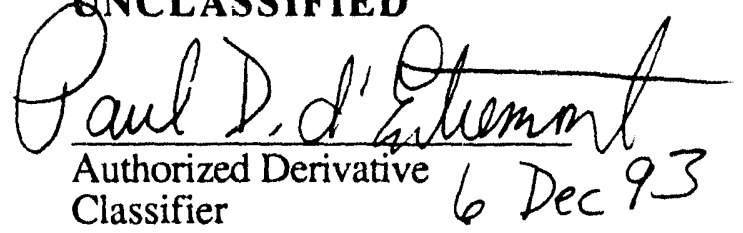


WSRC-TR-93-468

Revision 0

Page 2 of 37

APPROVALS

R. A. Jacobs, Technical Reviewer (Approved)

F. G. Smith, Technical Reviewer (Approved)

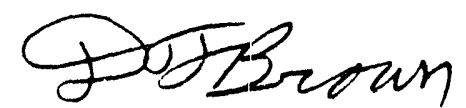

D. F. Brown, Technical Reviewer (Approved)

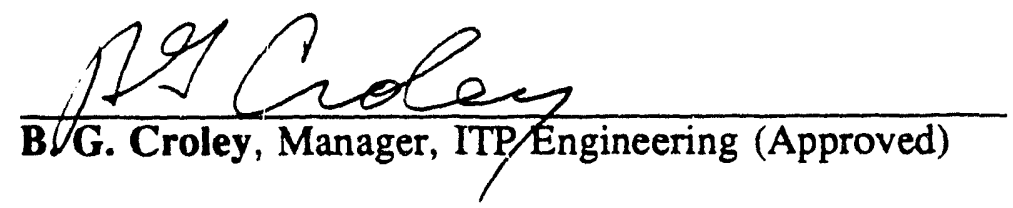

Date: $1-3 / y^{\prime}, 2$

Date: $12 / 3 / 92$

Date: $12 / 4 / 93$

Date: $12 / 11 / 93$ 
WSRC-TR-93-468

Revision 0

Page 3 of 37

TABLE OF CONTENTS

INTRODUCTION

SUMMARY

BACKGROUND

EXPERIMENTAL PROGRAM

Testing Methodology

8

DISCUSSION

11

Column Hydraulics

Stripping Efficiency

Application to ITP Column Operation

12

15

ACTIONS

16

REFERENCES 


\section{LIST OF FIGURES}

Figure 1. Schematic Diagram of Koch Pilot Scale Test Facility 24

Figure 2. Differential Pressure Data for Baseline Solution 25

Figure 3. Differential Pressure Data for Baseline Solution at $60^{\circ} \mathrm{C} \quad 26$

Figure 4. Differential Presssure Data For Standard Solution with 27 Antifoam Addition

Figure 5. Differential Pressure During DSS Column Simulation 28

Figure 6. Differential Pressure During WW Column Simulation 29

Figure 7. Differential Pressure During Column Operability Experiment 30

Figure 8. Impact of Temperature on Column Differential Pressure 31

Figure 9. Impact of Antifoam Addition on Column Differential Pressure 32

Figure 10. Benzene Removal During DSS Column Simulation 33

Figure 11. Benzene Removal During WW Column Simulation 34

Figure 12. Elimination of Variability in Column Differential Pressure 35 With Antifoam Use

\section{LIST OF TABLES}

Table I. Summary of Experiments Conducted During Pilot Scale 18 Stripper Testing

Table II. Feedstock Recipes for Pilot Scale Testing Program 20

Table III. Impact of Packing Arrangement on Column Performance 21

Table IV. Benzene Analysis of Samples Collected During Stripping 22 Testing 
WSRC-TR-93-468

Revision 0

Page 5 of 37

\section{INTRODUCTION}

Radioactive cesium will be removed from aqueous high level waste (HLW) solutions by precipitation with sodium tetraphenyl borate (TPB) in the In-Tank Precipitation (ITP) process. Benzene is generated due to the radiolysis of TPB, and dissolves into the decontaminated salt solution (DSS) and into the water used to "wash" (WW) the precipitate. These solutions will be processed through stripping columns to reduce the benzene concentration to satisfy limits for disposal of the DSS and for temporary storage of the WW.

Two columns will be used to strip the benzene - one column dedicated to each flow stream. Nitrogen will be used as the stripping medium, and will flow countercurrent to the liquid through structured packing. The diameter of the DSS column is 30 inches, and the diameter of the WW column is 16 inches. The DSS column was designed to process up to $115 \mathrm{gpm}$ of salt solution using $440 \mathrm{cfm}$ of nitrogen, while the WW column was designed for a maximum liquid rate of 33 gpm (typical flow of $14 \mathrm{gpm}$ ) and a nitrogen rate of $220 \mathrm{cfm}$.

During run-in testing of the large ITP column with simulated DSS, an excessively high differential pressure (DP) was observed at flow rates well below the maximum design rates. The liquid flow had been gradually increased to a maximum of $60 \mathrm{gpm}$, with the nitrogen flow rate set at $50 \mathrm{scfm}$. Flow through the column was discontinued when the DP was measured to be at the procedural limit of 25 inches of water column (wc). The operating limit was set based on the initial vendor recommendation for a maximum DP to prevent damage to the column internals. A bypass line was installed around the stripping columns, so that run-in testing could be completed for the remainder of the facility while more information was gained about the expected hydraulic performance of the columns.

Discussions with the column vendor (Koch Engineering Co.) indicated that the density and viscosity of the salt solution could have a small effect on the pressure drop across the packing relative to that of water. However, the maximum liquid and gas flows were far from the flooding point, as indicated by the vendor's DP correlations [1], and the impact of density and viscosity on the DP across the packing would essentially be insignificant. The observed high DP was attributed to another phenomenon, and after some discussion, Koch personnel agreed with the HLWE position that foaming was the likely cause.

To determine the effect of foaming and its implication on ITP column operation and performance, a test program was developed [2,3]. A series of tests was identified and performed at the Koch Engineering Co. site using a pilot scale facility. Test parameters were selected to evaluate hydraulic characteristics of the packing. Similarly, the stripping efficiency was also evaluated to verify the original design for benzene removal capability. A summary of the results of the testing program [4] and conclusions drawn from the data are documented in this report.

\section{SUMMARY}

A pilot scale testing program to evaluate the stripping column operation in support of ITP startup activities has been completed. Equipment and test plans were developed so that data obtained from the pilot scale testing would be directly applicable to full scale column operation and could be used to project hydraulic performance and stripping efficiency of both columns.

A review of the test data indicate that the ITP stripping columns will be capable of reducing benzene concentrations in salt solutions to satisfy Saltstone and Tank 22 acceptance limits. An 
WSRC-TR-93-468

Revision 0

Page 6 of 37

antifoam (AF) will be required to maintain the column differential pressure below the vendor recommendation of 40 inches wc so that design feed rates can be achieved. The high DP is caused by foaming, and the degree of foaming will vary for each solution. The antifoam will slightly reduce the stripping efficiency of the columns, but the resulting product streams are still expected to satisfy benzene concentration limits. More importantly, the nitrogen rate can be increased while using an antifoam to compensate for the loss of efficiency or for exceptionally high benzene levels in the feed without jeopardizing the DP limit. With AF injection, the benzene concentration in the DSS column bottoms is projected to be approximately $1.5 \mathrm{mg} /$, as compared to the Saltstone limit of $2.5 \mathrm{mg} / \mathrm{l}$. For the WW column, the outlet concentration is expected to be less than $2.1 \mathrm{mg} / \mathrm{l}$, as compared to the Tank 22 limit of $5 \mathrm{mg} /$. Additionally, the testing program indicated that the nitrogen rate can be decreased from the ITP column design rates and still satisfy benzene concentration requirements in the product.

\section{BACKGROUND}

The ITP benzene stripping columns were designed by E. I. Du Pont's Engineering Department based on operating experience from plants where benzene was stripped from water. No pilot testing was done to obtain design data specific to aqueous salt solutions, because stripping benzene from salt solution was considered to be easier than stripping benzene from water. The Henry's constant for benzene out of salt solution is greater than that for benzene out of water [5] implying that existing data would satisfy design needs as the most conservative case. No tests were planned by Du Pont to verify the column design; however, SRS personnel initiated a project to have a "proof of principle" test conducted at Du Pont's Engineering Test Center to verify stripping efficiency. The WSRC evaluation [6] of that test revealed that the experimental results [7] were corrupted due to maldistribution of the fluid streams.

The efficiency data from the testing were, however, salvaged and used for comparison with a mathematical model [8] to estimate the stripping efficiency of the ITP columns. The experimental results indicated that the benzene concentration in the DSS column product would be near and possibly above the $2.5 \mathrm{mg} / \mathrm{l}$ limit imposed due to Saltstone acceptance specifications. When a correction for the flow maldistribution was included, the calculated benzene concentration was below the acceptance limit, but still well above the design value.

Mass transfer in a stripping column is dependent on two factors - the vapor-liquid equilibrium and the rate of diffusion to the liquid-gas interface. Calculations using a mathematical model of the ITP stripping columns [8] indicated that the resistance of diffusion of benzene to the liquid-gas interface was considerably greater than the resistance of movement of benzene into the gas phase. Further, the rate of benzene diffusion in salt solution is much less than that for benzene in water due to the increased viscosity and censity of salt solution [9]. In such situations, use of a thin liquid film process is necessary to minimize the distance through which benzene must diffuse to reach the liquid-vapor interface (i.e., the thinner the film, the less the resistance to mass transfer). In a typical stripping column filled with structured packing, the extremely high surface area to volume ratio of the packing allows the liquid to form a very thin film on the packing surfaces [10]. Because the component is stripped at the liquid-gas interface, more surface area results in greater efficiency. In addition, the flow of liquid across the packing surface causes agitation of the liquid (i.e., surface renewal), effectively increasing the rate of benzene diffusion.

To have optimal conditions for mass transfer, the liquid and gas phases must be evenly distributed radially throughout the packing. Liquid and gas loading is specific to the type of packing. For a given gas rate, some minimum amount of liquid flow is necessary to provide an even distribution. 
As the liquid rate is increased, the loading increases, reducing the space for gas flow. The DP across the packing increases proportionally to the change in the liquid rate, until a point is reached where the rate of increase of DP becomes much more rapid. At this point, the DP is large enough to hold up liquid flow, flooding the packing [10]. Thus, proper operation is limited to a range of flow conditions. Operation outside of that window results in maldistribution (channeling) of one or both phases, increasing the film thickness on the packing and reducing the amount of liquid surface area to be contacted. The resistance to diffusion is greater while the area for mass transfer is lower, consequently reducing the stripping efficiency of the column.

Another variable that can cause flow maldistribution within the packing is foaming of the solution. At extremely low liquid and gas rates, stable flow patterns are possible, but as the liquid and/or gas rates increase, the foaming quickly increases. The foam causes increased resistance to flow and this is reflected in the differential pressure across the packing. The foam also forces the individual phases to seek a path of least resistance, thereby leading to channeling. Koch Engineering Co. has installed packed columns that process foaming solutions, but in all cases an antifoam is used to eliminate potential maldistribution and loss of packing efficiency due to foaming [11].

The solutions to be processed in ITP are expected to generate significant quantities of foam. When air is sparged through salt solution (before addition of ITP chemicals), a slight, unsteady foam develops. When soluble TPB is present, as in the ITP solutions, a large and stable volume of foam is generated, even when the gas sparging rate is relatively low [12]. Further, when a simulant of the latter solution was passed through a laboratory scale column packed with steel wool, a low countercurrent gas flow rate caused the entire packed volume to fill with foam [13]. As discussed above, the impact of foaming on the DP was observed in the run-in testing of the ITP columns.

Therefore, in order to improve the understanding of hydraulics within the columns when typical ITP solutions are processed, the test program discussed below was developed. The objective of the testing was to determine maximum processing capability in the columns, to evaluate potential methods to reduce and/or eliminate factors adversely affecting the throughput (i.e., foaming), and to confirm that stripping efficiency requirements will be satisfied.

\section{EXPERIMENTAL PROGRAM}

The test program was conducted at Koch Engineering Co.'s pilot scale research facility in Wichita, KS. An 8 inch diameter column was configured with two approximately $10 \mathrm{ft}$ beds of Type $1 Y$ Flexipac structured packing (total height of $20.3 \mathrm{ft}$ ). A collector/distributor was installed between the beds to allow sample collection for benzene analysis and to provide proper feed distribution in the bottom bed. For the last phase of the testing, the intermediate distributor was removed, and the beds combined to form one continuous $20 \mathrm{ft}$ bed (directly relatable to the ITP process columns).

Liquid was pumped to the column from either a 150 gal feed tank or from a tanker truck. Before entering the column, the feed solution passed through $1 \mu$ (nominal) cartridge filters to remove suspended solids. The liquid feed was maintained at constant temperature using a heat exchanger. Nitrogen was drawn from the facility's central supply, and was passed through a vessel filled with water to prehumidify the gas before introduction into the column. Nitrogen was maintained at 10 psig and $30^{\circ} \mathrm{C}$, and the column pressure was maintained at 10 psig. A schematic diagram of the test facility is shown in Figure 1. 
WSRC-TR-93-468

Revision 0

Page 8 of 37

Superficial liquid flow rates were varied between 1 and $25 \mathrm{gpm} / \mathrm{ft}^{2}$. The feed rates covered the range of flow conditions expected in the full scale DSS and WW columns, with $25 \mathrm{gpm} / \mathrm{ft}^{2}$

corresponding to maximum liquid design rates of $115 \mathrm{gpm}$ and $33 \mathrm{gpm}$, respectively. The nominal flow rate for the WW column is expected to be $14 \mathrm{gpm}$, represented in the test program by the superficial flow rate of $10 \mathrm{gpm} / \mathrm{ft}^{2}$. Similarly, the rate of nitrogen flow was varied over a range of conditions to simulate flow in both ITP columns. The flow was tracked using Koch's nornalized flow variable $F_{S}$, as defined in Eqn. 1. For the ITP process, $F_{S}$ is 0.52 (for $440 \mathrm{cfm}$ at $10 \mathrm{psig}$ and $30^{\circ} \mathrm{C}$ ) for the DSS column and is 0.89 (for $220 \mathrm{cfm}$ at $10 \mathrm{psig}$ and $30^{\circ} \mathrm{C}$ ) for the $W W$ column. The nitrogen rate was varied to cover the range $0.2 \leq \mathrm{F}_{\mathrm{s}} \leq 1.2$ to evaluate using more nitrogen if stripping efficiency did not match prescribed values, or using less nitrogen to minimize raw material costs.

$$
\mathrm{F}_{\mathrm{S}}\left[(\mathrm{ft} / \mathrm{sec}) \cdot\left(\mathrm{lb} / \mathrm{ft}^{3}\right)^{0.5}\right]=\mathrm{v}_{\mathrm{g}} * \rho_{\mathrm{g}} 0.5
$$

Column instrumentation included DP measurement across each bed of packing and across the entire column, and an overall column pressure measurement. Thermocouples were used to measure the temperatures of the column feed streams. Mass flow meters were used to measure the liquid and nitrogen flow rates. Liquid and gas flow rates and differential pressure data were monitored using the test facility's data acquisition system. Once flow rates were adjusted, the column DP was tracked and an average and standard deviation calculated for a 15 minute period. The column was considered to be operating in a stable regime when the DP remained steady for 15 minutes.

The main test program was divided into three phases. The first was to examine the hydraulic performance of the column without benzene in solution. The high DP observed in the ITP tests was reproduced and options for reducing the DP were evaluated. Maximum flow rates of feed and nitrogen that resulted in stable flow conditions and in column DP less than the revised Koch recommendation of 40 inches wc [14] were identified. These rates were used as a guide in setting flow conditions for the second phase of testing. The efficiency of the packing in removing benzene was measured during the second phase of the test, as well as determining the impact on efficiency caused by methods to reduce high DPs. In the final test phase, the column was physically reconfigured to simulate actual ITP column design as closely as possible. The column was operated to provide a directly relatable prediction for full scale operation, and the effect of changing specific variables was examined. A summary of all experiments in each testing phase and the objectives for each experiment are listed in Table I.

As part of the test program, several of the solutions were processed through a smaller, glass encased column filled with $3.5 \mathrm{ft}$ of Type I packing ( 8 inch diameter) so that a visual understanding of solution behavior was possible. Air (rather than nitrogen) was passed through the column, and no benzene was added to the feed. Differential pressure readings were taken from manometers installed on the column, but data were only used to make qualitative observations.

\section{Test Methodology}

\section{Experiment 1}

The first phase of testing was concerned with determining hydraulic capabilities of the column without having benzene present. In Experiment 1, the dry bed (no liquid flow) pressure drops for 
WSRC-TR-93-468

Revision 0

Page 9 of 37

the column were determined initially to verify that there were no problems with the packing. Nitrogen was passed through the column at various rates, and the differential pressure across the column was measured. Differential pressures per unit height of packing for Experiment 1 are shown in Figure 2.

\section{Experiment 2}

Following the dry bed runs, a 150 gal batch of salt solution was prepared as a baseline feedstock. Dry chemicals were mixed with DI water to prepare the solution at the composition specified in Table II. The amount of NaTPB added was only about $25 \%$ of the amount needed to fully precipitate all the potassium and reach the solubility limit of NaTPB. As described earlier, the high DPs in the ITP runs were attributed to foaming caused by the presence of soluble TPB. With only a minimal amount of TPB added, the solution provided a baseline of a mirimally foaming salt solution.

In the second experiment, the baseline feedstock was processed through the column at liquid rates ranging from 1 to $25 \mathrm{gpm} / \mathrm{ft}^{2}$. The column bottoms were recycled to the feed tank and the liquid temperature was maintained at $30^{\circ} \mathrm{C}$. Nitrogen flow was varied to cover the range of $F_{S}$ between 0.2 and 1.2 for each constant liquid rate. The traditional family of DP curves was generated and plotted along with the dry bed DP data in Figure 2. It should be noted that the slope of the 20 and $25 \mathrm{gpm} / \mathrm{ft}^{2}$ curves begins to increase at the higher values of $F_{s}$, indicating the approach to flooding conditions.

\section{Experiment 3}

In Experiment 3, the impact of a higher feed temperature was evaluated. An increase in temperature reduces the density and viscosity of liquids, and was consequently expected to alter the flow characteristics through the packing. The extent of the change in the liquid properties was anticipated to reduce and hopefully eliminate the quantity of stable foam formed. The feed temperature was raised to $60^{\circ} \mathrm{C}$, which is the maximum expected temperature during ITP processing. Liquid and gas rates were again varied over a wide range of flows to generate the loading curves, and these are shown in Figure 3. Because of difficulty in maintaining the test facility at the higher temperatures, operation at $25 \mathrm{gpm} / \mathrm{ft}^{2}$ was stopped after data were collected for a nitrogen $F_{\mathrm{s}}$ rate of 0.6 .

\section{Experiment 4}

Following the high temperature run, a new batch of salt solution was prepared. Sodium TPB was added in sufficient quantity to precipitate all of the potassium and to allow some NaTPB to remain in solution. The objective of Experiment 4 was to ramp up the flows to determine the maximum stable operating point. However, even at low liquid and nitrogen rates, a stable operating point could not be obtained. Thus, the series of curves to compare against the baseline could not be generated. A small batch of the solution was also run through the glass column, and analogously high DPs were noted. Foam was observed, confirming the HLWE position that foaming was the cause of the high DPs during run-in of the ITP column.

\section{Experiment 5}


As the solution continued circulating through the test column, antifoam (AF) was injected into the feed line to reduce the foam and lower the DP. Tri-n-butyl phosphate was used as the AF, and was injected at a target concentration of $100 \mathrm{ppm}$. (Tri-n-butyl phosphate was recommended based on results of laboratory testing of several antifoams and a screening evaluation of the general classes of commercially available antifoams $[12,15]$.) The DP across the column immediately dropped to manageable levels and conditions within the column rapidly stabilized. Column operation remained stable over the entire range of liquid and gas rates. Differential pressures for the conditions in Experiment 5 are shown in Figure 4.

At the conclusion of Experiment 5, the column was flushed and cleaned with oxalic acid to remove any solids that may have accumulated in the packing or in the distributors and to flush the system of residual antifoam.

\section{Experiment 6}

In Experiment 6, the stripping efficiency of the ITP columns when processing DSS was evaluated. Simulated DSS was prepared by a third-party vendor and shipped to the test facility in a $4000 \mathrm{gal}$ tanker. The solution was spiked with benzene and TPB (the recipe is shown in Table II) during preparation, but additional benzene and TPB were added by Koch personnel to make up for losses and consumption by excess potassium impurities, respectively. The solution was drawn directly from the tanker and was processed th. ough the column in single pass mode (i.e., no recycle). Nitrogen flow was set to an $F_{s}$ of 0.5 . Liquid feed rate was initially set to $10 \mathrm{gpm} / \mathrm{ft}^{2}$ to simulate WW column feed during initial precipitate washing at ITP. The feed rate was then increased to 25 $\mathrm{gpm} / \mathrm{ft}^{2}$ to simulate DSS column operation. No AF was injected during this duration, as the column DP remained relatively stable and below the 40 inches wc limit recommended by Koch. After about 1.5 hours of operation, the antifoam injection system was started. Differential pressure across the column dropped to levels comparable to those in Experiment 5. Samples of the feed, bottoms and mid-column flows were collected throughout Experiment 6 for benzene analysis. A time trace of the column DP throughout Experiment 6 (including highlights of significant events) is shown in Figure 5.

\section{Experiment 7}

The stripping efficiency of the column when processing simulated WW was evaluated in Experiment 7. Deionized water was added to the feed solution remaining in the tanker to dilute the salt concentration. Additional TPB and benzene were added, and the solution was mixed overnight in the tanker. As before, the initial feed rate was set to $10 \mathrm{gpm} / \mathrm{ft}^{2}$ (nominal WW column processing rate) and processed through the column in single pass mode. The nitrogen rate was set to an $F_{S}$ of 0.5 . After 2 hours of operation, the feed rate was increased to about $23 \mathrm{gpm} / \mathrm{ft}^{2}$. The DP across the column steadily increased ver the next 3.5 hours of operation, as is shown in the time trace in Figure 6. At that point, contunuous AF injection was started. The DP dropped almost instantly and remained steady until the conclusion of the run. Feed, bottoms and mid-column samples were collected for benzene analysis throughout the experiment.

\section{Experiment 8}

The column was flushed and cleaned with oxalic acid to remove any traces of solids and antifoam that may have collected. In preparation for the final testing phase, the packing was reconfigured to a single, $20 \mathrm{ft}$ bed of packing to represent the ITP stripping columns. An additional injection 
WSRC-TR-93-468

Revision 0

Page 11 of 37

system was added, so that both benzene and antifoam could be separately introduced into the feed stream. A 150 gal batch of salt solution was prepared using the third recipe shown in Table I. Sodium TPB was added to precipitate the potassium (present as impurities in the sodium salts), with enough excess to saturate the solution. The system was operated in recycle mode, and the six parts of Experiment 8 were conducted without interrupting feed flow. Feed temperature was maintained at $30^{\circ} \mathrm{C}$. Three sets of feed and bottoms samples were collected at 15 minute intervals once column conditions remained steady for 30 minutes.

In Experiment 8A, the impact of operation at a lower nitrogen rate was evaluated. The liquid rate was set to $25 \mathrm{gpm} / \mathrm{ft}^{2}$, and the nitrogen flow was set to an $F_{S}$ of 0.2 . No antifoam was used in this experiment. Benzene was injected at a rate such that the resulting concentration in the feed was $100 \mathrm{mg} / \mathrm{l}$. The column DP remained steady and below the 40 inches wc limit, as shown in the time trace in Figure 7. Samples were collected once column conditions appeared stable.

The nitrogen flow was then increased to an $\mathrm{F}_{\mathrm{S}}$ of 0.5 for Experiment $8 \mathrm{~B}$, still without the use of antifoam. When the DP increased well above 60 inches wc, the benzene concentration was raised to about $200 \mathrm{mg} / \mathrm{l}$ to determine if the foam reducing qualities of benzene would be adequate to reduce the DP to less than 40 inches. However, the liquid rate was decreased to about $22 \mathrm{gpm} / \mathrm{ft}^{2}$ in an attempt to stabilize the DP across the packing. Although column DP and flow rates were not steady through Experiment $8 \mathrm{~B}$, samples were collected for benzene analysis.

In Experiment $8 \mathrm{C}$, the feed and nitrogen rates were further reduced to about $20 \mathrm{gpm} / \mathrm{ft}^{2}$ and an $\mathrm{F}_{S}$ of 0.3 to evaluate whether the lower flows and the high benzene concentration would result in steady column DP. Samples were collected when the column DP reached a pseudo-steady state.

In Experiments 8D and 8E, the impact of antifoam on stripping efficiency was evaluated. The liquid and gas rates were restored to design flows $\left(25 \mathrm{gpm} / \mathrm{ft}^{2}\right.$ and $\mathrm{F}_{\mathrm{S}}$ of 0.5$)$. Benzene was injected to give a target concentration of $200 \mathrm{mg} / \mathrm{l}$. Antifoam addition was started at approximately $100 \mathrm{ppm}$. Sampling was started as soon as the column DP reached a stable point, and conditions were maintained for 1.75 hours after the first samples were collected.

Finally, the nitrogen rate was increased to an $F_{S}$ of 0.9 while keeping the liquid feed rate constant to simulate the design nitrogen flow in the WW column. The antifoam injection rate was increased to counter the increase in DP, resulting in an estimated concentration of about $200 \mathrm{ppm}$. (Note that the AF injection system continued to run in this recycled feed arrangement; the actual concentration of AF in solution going to the column was higher.) A final set of three samples was collected after the column DP stabilized.

All raw operating and sample data collected during the testing are included in the Project Report prepared by Koch [4]. The original copy of the report is filed with the Record copy of this document.

\section{DISCUSSION}

\section{Column Hydraulics}

Two sources contributed to the high differential pressure across the column - the foam from the salt solution itself, and the foam due to the presence of soluble TPB. Four recipes were used to prepare feedstocks with TPB over the course of the test. The resulting solutions were all observed 
WSRC-TR-93-468

Revision 0

Page 12 of 37

to foam to differing degrees; consequently, the magnitude of the pressure drop across the packing varied depending on the solution being processed.

The effect of temperature on reducing the column DP was found to be only marginal. The temperature of the baseline solution was raised to $60^{\circ} \mathrm{C}$, simulating operation in ITP at the upper temperature limit. The increased temperature was expected to reduce the "consistency" of the liquid, making it much harder for a stable foam to form. As seen in Figure 8, the DP at $60^{\circ} \mathrm{C}$ was somewhat less than that seen for the same solution at $30^{\circ} \mathrm{C}$, at liquid rates of 10 and $25 \mathrm{gpm} / \mathrm{ft}^{2}$. Because of the difficulty in operation of the test facility at the higher temperature:, operation at 25 $\mathrm{gpm} / \mathrm{ft}^{2}$ was stopped after data were collected for a nitrogen $F_{\mathrm{S}}$ rate of 0.6 . However, the same general relationship of the low temperature curves to the high temperature curves (as at $10 \mathrm{gpm} / \mathrm{ft}^{2}$ ) is expected.

The most drastic reduction in the column DP was observed when antifoam was present in the feed solution. The DP values were expected to be roughly the same as those of the baseline solution, but as is evident in Figure 9 for liquid loading of $25 \mathrm{gpm} / \mathrm{ft}^{2}$, the DP across the column was well below the DP observed when the baseline solution was run through the column. For comparison, calculated DP values for the nitrogen-water system [16] are also shown in Figure 9, indicating that the antifoam works to reduce the pressure drop to levels approaching an "ideal" limit. At liquid flows comparable to maximum rates in the DSS and WW columns, the observed column DP was 1.9 and 11 inches wc $\left(0.095\right.$ and 0.55 inches $\left.\mathrm{H}_{2} \mathrm{O} / \mathrm{ft}\right)$, respectively.

It is interesting to note that benzene did exhibit some antifoam tendencies, but these were not consistently observed over the course of the testing. The salt solution prepared by the third party vendor did not create as much foam as the solutions prepared at the test facility, and the presence of benzene likely contributed to the reduction in the amount of foaming. This solution was processed through the column at maximum liquid rates without injection of antifoam. As seen in Figure 5, the column DP did not reach 20 inches wc. The antifoam properties of benzene were also observed during Experiment 8, where the DP was reduced from over 80 inches wc to less than 5 inches wc during the startup phase of the experiment. Alternatively, though, in Experiment 7, the column DP gradually continued increasing, even in the presence of increasing benzene concentrations. Because of the ambiguity in the DP data and considering the variability of the feedstocks, the magnitude of the antifoam properties of benzene could not be conclusively established.

The impact of having the packing arranged into two $10 \mathrm{ft}$ beds versus a single $20 \mathrm{ft}$ bed did not have a significant effect on the column DP at nitrogen flow rates corresponding to an $\mathrm{F}_{\mathrm{s}}$ below 0.5 . As summarized in Table III, at $25 \mathrm{gpm} / \mathrm{ft}^{2}$ and an $\mathrm{F}_{\mathrm{s}}$ of 0.5 , the DP in the two configurations differed only by about $0.01 \mathrm{inch} / \mathrm{ft}$. However, at a nitrogen $\mathrm{F}_{\mathrm{s}}$ of 0.9 , the DP differed by 0.1 inch/ft. The amount of variation would be expected to be greater at higher column loadings, because of the approach to flooding and flow instability. The intermediate collector/distributor redistributed the liquid and gas flows, thus removing any problem spots that were created in the upper packing. Koch normally recommends that packing be split every 15-25 ft (depending on the fluid and the type of packing) so that flows can be redistributed to maintain the mass transfer efficiency of the packing [17].

Reduced nitrogen flow was also evaluated as a way of reducing the packing DP to levels that are acceptable, assuming that the bottoms benzene concentration will be within limits. In Experiment $8 \mathrm{~A}$, the nitrogen rate was reduced to an $\mathrm{F}_{\mathrm{s}}$ of 0.2 . The DP across the column was not steady 
WSRC-TR-93-468

Revision 0

Page 13 of 37

throughout the experiment, and the average DP was calculated to be about 23 inches wc. As seen in the time trace in Figure 7 (at an elapsed time of about 60 minutes), the DF slowly decreased, indicating that a steady flow pattern had not been established. In comparison, in a well behaved system, the column flows would quickly find a steady flow pattern, and the DP would stabilize within 10-15 minutes.

In reviewing all test data with respect to hydraulics, the greatest success in consistently and effectively reducing the column DP was concluded to be due to the addition of antifoam (tri-n-butyl phosphate). Increased temperature does result in a small but marginally significant reduction in DP. Operation at low nitrogen rates will necessarily reduce the pressure drop, but steady flow conditions (and consequently DP) were not observed over a 2 hour period. Only the antifoam addition reduces/eliminates the foam, which puts the column into the operating regime consistent with the vendor recommendation of column operation [4].

\section{Stripping Efficiency}

During the second and third phases of the test program, samples were collected and submitted for benzene analysis. During Experiments 6 and 7, all samples were analyzed by Koch personnel. One of the three sets of samples collected during each part of Experiment 8 was shipped to WSRC and analyzed in the ITP laboratory. Analysis of the remaining two sets of samples was completed by Koch personnel. Analyses by both laboratories were performed using the purge and trap method. All analytical data for the Stripping Efficiency portion of the testing are listed in Table IV.

It is interesting to note that some analyses of feed solutions reflect benzene concentrations that are higher than the solubility limit. These analyses were assumed to be correct in the context of determining the stripping efficiency in terms of the total amount of benzene stripped and to represent an entrained second phase of benzene. (For future evaluation of these data for stripping efficiency in terms of transfer units, the saturation concentration should be used.) Concentrations reported in Table IV for the samples analyzed at ITP have been corrected to account for benzene losses during the 6 day transit time. Losses of approximately $10 \%$ per day have been experimentally observed [18] from glass sample vials with teflon-lined caps for low concentration samples, such as those used in this testing program. It is recognized that the corrected analytical results still have a large degree of uncertainty, but because the values are only used for comparison of operating parameters in this review, the uncertainty is considered acceptable. Samples which were noted to be leaking upon receipt at the ITP lab have been highlighted in Table IV. The analytical results for the leaking samples are not included in the discussion below since a large fraction of the benzene in the sample would likely have escaped.

Benzene was consistently stripped from the high Na solution (DSS simulant) in Experiment 6, both before and after initiation of antifoam injection. At a liquid rate of $10 \mathrm{gpm} / \mathrm{ft}^{2}$, a nitrogen $F_{\mathrm{s}}$ of 0.5 and with no antifoam addition, the benzene concentration in the feed ranged from about 60 to $260 \mathrm{mg} / \mathrm{l}$, and was reduced in all cases to $1.5 \mathrm{mg} / \mathrm{l}$ or less. The feed and bottoms concentrations are shown in Figure 10. When the liquid rate was increased to $25 \mathrm{gpm} / \mathrm{ft}^{2}\left(\mathrm{~F}_{s}\right.$ of 0.5 and no antifoam), the benzene concentration was reduced to less than $0.5 \mathrm{mg} / 1$. Feed concentrations ranged from about 170 to $280 \mathrm{mg} /$. Finally, when the antifoam injection system was started (still keeping the feed and nitrogen flows constant), the benzene feed concentration of 210 to $250 \mathrm{mg} / \mathrm{l}$ was reduced to less than $1.5 \mathrm{mg} /$. 
WSRC-TR-93-468

Revision 0

Page 14 of 37

The benzene concentration in the bottoms of the simulated WW solution (Experiment 7) was consistently reduced to $2.1 \mathrm{mg} / \mathrm{l}$ or less. Starting at a liquid rate of $10 \mathrm{gpm} / \mathrm{ft}^{2}$ and a nitrogen $\mathrm{F}_{\mathrm{s}}$ of 0.5 and no antifoam, benzene in the feed $(560$ to $1050 \mathrm{mg} / \mathrm{l})$ was reduced to a concentration less than $0.9 \mathrm{mg} / 1$. The feed rate was then increased to about $23 \mathrm{gpm} / \mathrm{ft}^{2}$. For benzene feed concentrations ranging from 250 to $950 \mathrm{mg} /$, the bottoms benzene concentration was less than or equal to $1.7 \mathrm{mg} / 1$. During antifoam addition at the same feed and nitrogen rates, the bottoms concentration was analyzed to be $2.1 \mathrm{mg} / \mathrm{l}$ or less for feed concentrations from 450 to $970 \mathrm{mg} /$. Benzene concentrations in the feed and bottoms samples collected during Experiment 7 are shown in Figure 11.

Mid-column samples collected during Experiments 6 and 7 at the distributor/collector positioned between the two beds of packing reflected that most of the stripping was occurring in the top half of the column, as expected. Benzene concentrations of the mid-column samples are shown with the respective feed and bottoms values in Figures 10 and 11.

Throughout Experiment 8, the stripping efficiency of the column changed significantly, as expected, as a function of the variation in the test conditions. In Experiment $8 \mathrm{~A}$ with the nitrogen $F_{s}$ at 0.2 , the liquid rate at $25 \mathrm{gpm} / \mathrm{ft}^{2}$ and no antifoam, the bottoms concentration was reduced to below $1.0 \mathrm{mg} / \mathrm{l}$ for feed ranging from 110 to $150 \mathrm{mg} / \mathrm{l}$ benzene. As the benzene injection rate was increased and the nitrogen rate adjusted to minimize the column DP during Experiments $8 \mathrm{~B}$ and $8 \mathrm{C}$, bottoms benzene concentrations ranged from less than $1 \mathrm{mg} / \mathrm{l}$ to over $30 \mathrm{mg} /$. During the antifoam injection at design liquid and gas flow rates $(8 \mathrm{D}$ and $8 \mathrm{E})$, the feed concentration ranged between 80 and $340 \mathrm{mg} /$. The benzene concentration in the bottoms varied between 1.1 and 22 $\mathrm{mg} /$. Finally, with the nitrogen $F_{\mathrm{s}}$ set to 0.9 , benzene in the feed was between 120 and $260 \mathrm{mg} /$, and the bottoms concentration was between 20 and $25 \mathrm{mg} /$.

Operation and separation efficiency did not consistently follow typical operating behavior when foam was present (indicated by the high DP). An increase in the liquid rate for a constant nitrogen rate would normally decrease the stripping efficiency, and would be reflected in an increase in the bottoms benzene concentration. However, in Experiment 6, the bottoms concentration was seen to decrease from about $1.5 \mathrm{mg} / \mathrm{l}$ to $0.4 \mathrm{mg} / \mathrm{l}$ when the feed flow rate was increased from 10 to 25 $\mathrm{gpm} / \mathrm{ft}^{2}$ (samples $6 / 3$ and $6 / 4$ were compared to samples $6 / 6$ and $6 / 7$ based on roughly similar feed concentrations). Similarly for the step change in liquid rate during Experiment 7, samples $7 / 3$ and $7 / 4$ were compared to samples $7 / 8$ through $7 / 10$. The bottoms concentration of the latter samples was observed to be almost the same as the concentration of the former. The opposite behavior is likely due to improved mass transfer as a result of the increased surface area caused by the foaming, which can also be linked to the column DP. As can be seen in Figure 4 for non-foaming salt solution, an increase in the liquid rate from $10 \mathrm{gpm} / \mathrm{ft}^{2}$ to $25 \mathrm{gpm} / \mathrm{ft}^{2}$ at an $\mathrm{F}_{\mathrm{S}}$ of 0.5 would cause the DP across the packing to increase by a factor of 2.2. However, the data in Figures 5 and 6 reflect an increase in differential pressure of at least an order of magnitude for the same change in feed flow rate. This non-proportional increase is due to foaming, reflected by the lower bottoms concentration at increased liquid feed rate.

This degree of improvement, however, was dependent on the foaming characteristics of the feed solution and the relative "distance" from a flooding or unsteady condition. In Experiments $8 \mathrm{~B}$ and $8 \mathrm{C}$, an increase in the nitrogen rate (expected to increase the column stripping efficiency) caused the DP to widely fluctuate, as seen on the time trace in Figure 7. The solution used in Experiment 8 foamed to a greater extent than the solution in Experiments 6 and 7, and thus a small increase in liquid or gas rate resulted in an increase in foaming and a large swing in DP. As discussed in the 
WSRC-TR-93-468

Revision 0

Page 15 of 37

Hydraulics section, foaming causes flow instabilities through the packing. Feed solution was not completely contacted with nitrogen, and this was reflected in the widely varying benzene concentrations in the column bottoms during Experiment $8 \mathrm{~B}$ and $8 \mathrm{C}$ (seen in Table IV).

The use of tri-n-butyl phosphate to reduce/eliminate foaming appeared to have a slight negative effect on the benzene stripping. In Experiment 6, at a feed rate of $25 \mathrm{gpm} / \mathrm{ft}^{2}$ and a nitrogen $F_{\mathrm{s}}$ of 0.5 , the average benzene concentration in the bottoms before antifoam addition was $0.4 \mathrm{mg} /$, while after the AF addition started, the average concentration was observed to be $1.1 \mathrm{mg} /$. Antifoam was injected at a concentration of $75 \mathrm{ppm}$. Similarly, in Experiment 7 (for feed concentrations above $700 \mathrm{mg} / \mathrm{l}$ ), the average bottoms concentration increased from $0.7 \mathrm{mg} / 1$ to 2.0 $\mathrm{mg} / \mathrm{l}$ following introduction of antifoam at approximately $75 \mathrm{ppm}$. During these two experiments, the feed solution was not recycled.

The reduction in stripping efficiency appears to be proportional to the amount of AF present. In Experiment 8, the AF was continuously injected at a concentration of $76 \mathrm{ppm}$ into the feed, which was recycled into the 150 gal feed tank. The AF was continuously injected throughout Experiment 8 because, in earlier hydraulic tests using recycled feed, the DP was observed to begin increasing once the injection was stopped. At the feed rate of $25 \mathrm{gpm} / \mathrm{ft}^{2}$, the tank contents were turned over at least twice before the first samples were collected, and at least 10 times during the 3.5 hour duration of Experiments $8 \mathrm{D}$ and $8 \mathrm{E}$. The bottoms concentration during Experiment $8 \mathrm{D}$ averaged $2.4 \mathrm{mg} /$, indicating that an overall concentration of $150-230 \mathrm{mg} / \mathrm{AF}$ would reduce the stripping efficiency. The concentration of AF in the tank was estimated to have eventually reached approximately $800 \mathrm{ppm}$ during Experiment $8 \mathrm{E}$, but the amount actually flowing to the column (as dissolved and/or entrained) was not determined. The average concentration of bottoms samples for Experiment $8 \mathrm{E}$ was about $22 \mathrm{mg} /$. Further, in Experiment $8 \mathrm{~F}$, the nitrogen rate was increased and the AF injection rate was approximately doubled to counter the increased DP across the packing. At the higher nitrogen rate, more efficient stripping was expected, but the average bottoms benzene concentration was observed to increase slightly to about $23 \mathrm{mg} /$.

The stripping efficiency of the continuous packed bed was expected to be slightly less than the efficiency in the split packing arrangement, but a review of the data was inconclusive.

Finally, it was observed that a lower nitrogen rate can be used to strip benzene to acceptable levels. During Experiment 6 at a liquid rate of $25 \mathrm{gpm} / \mathrm{ft}^{2}$, the feed solution $(170-280 \mathrm{mg} / \mathrm{l}$ benzene, no $\mathrm{AF}$ ) was stripped of benzene to $0.4 \mathrm{mg} / \mathrm{l}$ with nitrogen set at an $\mathrm{F}_{\mathrm{s}}$ of 0.5 . In Experiment $8 \mathrm{~A}$, benzene in the feed was reduced from $110-150 \mathrm{mg} / \mathrm{l}$ to an average of $0.6 \mathrm{mg} / \mathrm{l}$ with nitrogen set to an $F_{s}$ of 0.2 . The bottoms value would have been somewhat higher if the feed concentration matched that in Experiment 6, but likely no more than $1.2 \mathrm{mg} / \mathrm{l}$.

\section{Application to ITP Column Operation}

The data obtained from the testing program can be used to make direct inferences regarding actual column operation with a strong degree of confidence. Koch normally uses this test facility to troubleshoot the operation of full sized commercial packed columns, as well as gathering data to be used in column design. The 8 inch column diameter is large enough to provide proper radial distribution and behavior without significant wall effects. The height of the packing was set to $20.3 \mathrm{ft}$ to match the ITP columns. Additionally, data for a split bed arrangement (used for most of the testing) were compared to data for a continuous bed configuration, and very little difference was observed for similar test conditions. In the discussion that follows, the projections for the 
WSRC-TR-93-468

Revision 0

Page 16 of 37

full-scale ITP columns are based on the most conservative data collected from all of the experiments.

Maximum liquid flow rates will only be attainable when an antifoam is used to eliminate foaming and control the DP to values well below 40 inches wc. Each batch of salt solution will necessarily be different from all others, resulting in varying degrees of foaming and pressure drop across the packing. Consequently, the maximum processing rate through the column will also vary in order to maintain the 40 inch DP limit. The four solutions used during the test program foamed to varying extents, but the variability was removed by the use of an antifoam. As shown in Figure 12 for three of the experiments, the degree of variability was reflected in the wide changes in column DP. However, once the addition of AF was initiated, the column DPs fell to a level of about 2 inches wc and remained steady. The solutions were forced to a common level, such that DP was reproducible for the different solutions. Therefore, based on the testing and the vendor recommendation [4], the antifoam must be used to consistently meet design flow rates for the columns.

The use of an antifoam appeared to have a slight negative effect on the stripping efficiency. The quantity of $\mathrm{AF}$ used should be minimized to maintain the stripping efficiency as high as possible (Experiments 8D-8F). However, the nitrogen rate can be increased to accomodate the slight loss in efficiency (or even an exceptionally high benzene concentration) without causing the DP limit to be exceeded.

Based on data from Experiment 5, the DP across the packing in the DSS column is projected to be on the order of 6-8 inches wc (with ca. $75 \mathrm{ppm}$ antifoam) at a nitrogen rate of $440 \mathrm{cfm}$. For a benzene concentration in the feed up to $200 \mathrm{mg} /$, the bottoms concentration is expected to be approximately $1.5 \mathrm{mg} / \mathrm{l}$ at the maximum feed rate of $115 \mathrm{gpm}$, as observed in Experiment 6 . The Saltstone feed acceptance limit is $2.5 \mathrm{mg} /$. However, as the feed rate declines to the stripper (based on filtrate production upstream), the amount of stripping will improve, lowering the bottoms concentration further. The amount of nitrogen needed to satisfy the Saltstone limit may be less (Experiment 8A) than $440 \mathrm{cfm}$, depending on the impact that antifoam will have on stripping efficiency in actual operation.

Similarly, for the WW column, the DP across the column during the initial stages of precipitate washing will be on the order of 22 inches wc at $220 \mathrm{cfm}\left(F_{s}\right.$ of 0.9$)$ and maximum feed rate of 33 $\mathrm{gpm}$, as seen in Experiment 5. At the nominal feed rate of $14 \mathrm{gpm}$, the DP is projected to be 8-10 inches wc, also based on data from Experiment 5 . Benzene in the bottoms should be at a concentration well below the $5 \mathrm{mg} / \mathrm{l}$ limit for wash water being transferred to Tank 22 . The maximum concentration observed during Experiments 6 and 7 was $2.1 \mathrm{mg} / \mathrm{l}$, at feed concentrations on the order of $900 \mathrm{mg} / \mathrm{l}$ and at a nitrogen rate of approximately $110 \mathrm{cfm}$ (half the design rate). Thus, the nitrogen rate can be significantly reduced from the design rate for the WW column.

In summary, the ITP stripping columns will be capable of reducing benzene concentrations to satisfy Saltstone and Tank 22 acceptance limits. Antifoam is required to maintain the column differential pressure below the vendor recommendation of 40 inches wc so that design feed rates can be achieved. The antifoam slightly reduces the stripping efficiency of the columns, but the resulting product streams still satisfy benzene concentration limits. Alternatively, the nitrogen rate can be increased to compensate for the loss of efficiency or for exceptionally high benzene levels in the feed without jeopardizing the DP limit. With AF injection, the benzene concentration in the DSS column bottoms is projected to be approximately $1.5 \mathrm{mg} /$, as compared to the Saltstone limit of $2.5 \mathrm{mg} /$. For the WW column, the outlet concentration is expected to be less than $2.1 \mathrm{mg} /$, as 
WSRC-TR-93-468

Revision 0

Page 17 of 37

compared to the Tank 22 limit of $5 \mathrm{mg} / \mathrm{l}$. Additionally, the testing program indicated that the nitrogen rate can potentially be decreased and still satisfy benzene concentration requirements in the product.

\section{ACTIONS}

NONE

\section{REFERENCES}

[1] K. J. McNulty and C. Hsieh, "Hydraulic Performance and Efficiency of Koch Flexipac Structured Packings", Paper presented at the 1982 Annual Meeting of the AIChE, November 14-19, 1982.

[2] G. K. Georgeton, "Pilot Scale Stripping Column Test Program (U)", WER-HLE-930653, March 16, 1993.

[3] G. K. Georgeton, "Pilot Scale Stripping Column Test Program: Modification to Scope of Work", WER-HLE-930727, April 14, 1993.

[4] R. L. Hardy, Koch Distillation Pilot Plant Test Report for Westinghouse Svannah River Co, Koch Engineering Co., May 20, 1993.

[5] D. D. Walker, "Vapor Pressure of Benzene, Methanol, and Isopropanol Over Salt Solutions", DPST-88-661, March 28, 1989.

[6] G. K. Georgeton and B. M. Wilson, "Analysis of ETC Test Results for Benzene Removal with Structured Packing (U)", WSRC-RP-89-871, September 12, 1989.

[7] M. E. Meckley, Memo to G. K. Georgeton and J. P. Wood, "Petrochemicals Department Savannah River Plant - Mass Transfer - Benzene Stripping - ETC Pilot Study", March 31, 1989.

[8] G. K. Georgeton, "Development and Application of a Mathematical Model for the Benzene Stripping Columns in the ITP Process (U)",

[9] D. D. Walker and G. K. Georgeton, "Viscosity and Density of Simulated Salt Solutions", WSRC-RP-89-1088, October 19, 1989.

[10] R. E. Treybal, Mass Transfer Fundamentals, Third Edition, Chapter 6, McGraw Hill Book Company, New York, 1980.

[11] P. Tokerud, Koch Engineering Co., personal communication, February 23, 1993.

[12] M. J. Barnes and J. F. McGlynn, "Lab Scale Defoaming Tests on the In-Tank Precipitation Benzene Stripper Columns (U)", SRT-LWP-93-021, March 19, 1993.

[13] J. F. McGlynn, personal communication, June 1, 1993.

[14] D. Svaldi, Koch Engineering Co., Memo to T. P. Gaughan, February 25, 1993. 
WSRC-TR-93-468

Revision 0

Page 18 of 37

[15] J. P. Bibler, "Other Antifoaming Agents for the ITP Stripper", SRT-LWP-93-032, April 13, 1993.

[16] Koch Tower Design ${ }^{\mathrm{TM}}$ Tray and Packing Rating Software, Koch Engineering Co., Inc., calculations performed using software for the nitrogen-water system; nitrogen at $10 \mathrm{psig}$ and $30^{\circ} \mathrm{C}$, water at $30^{\circ} \mathrm{C}$.

[17] P. Tokerud, Koch Engineering Co., personal communication, May 19, 1993.

[18] D. D. Walker, "Sample Containers for Solutions Containing Benzene", IWT-LWP-91-010, February 26, 1991. 
WSRC-TR-93-468

Revision 0

Page 19 of 37

\section{Table I. Summary of Experiments Conducted During Pilot Scale Stripper Testing}

\begin{tabular}{|c|c|c|c|}
\hline Experiment & Column & Conditions & Objectives \\
\hline Phase 1 & & & \\
\hline 1 & $\begin{array}{l}\text { Nitrogen: } \\
\text { Feed: } \\
\text { Benzene: }\end{array}$ & $\begin{array}{l}0.2 \leq \mathrm{F}_{\mathrm{s}} \leq 1.2 \\
0 \mathrm{gpm} / \mathrm{ft}^{2} \\
0 \mathrm{mg} / 1\end{array}$ & - Establish Dry Bed DP \\
\hline 2 & $\begin{array}{l}\text { Nitrogen: } \\
\text { Feed: } \\
\text { Benzene: } \\
\text { Low TPB, Ten } \\
\text { No Antifoam, }\end{array}$ & $\begin{array}{l}0.2 \leq \mathrm{F}_{\mathrm{s}} \leq 1.2 \\
1-25 \mathrm{gpm} / \mathrm{ft}^{2} \\
0 \mathrm{mg} / \\
\mathrm{np}=30^{\circ} \mathrm{C} \\
\text { DSS Simulant }\end{array}$ & $\begin{array}{l}\text { Establish Baseline for Minimally Foaming } \\
\text { System } \\
\text { Determine DP as Function of Feed and Gas } \\
\text { Rates }\end{array}$ \\
\hline 3 & $\begin{array}{l}\text { Nitrogen: } \\
\text { Feed: } \\
\text { Benzene: } \\
\text { Low TPB, Ten } \\
\text { No Antifoam, }\end{array}$ & $\begin{array}{l}0.2 \leq \mathrm{F}_{\mathrm{s}} \leq 1.2 \\
1-25 \mathrm{gpm} / \mathrm{ft}^{2} \\
0 \mathrm{mg} \hat{\Lambda} \\
\mathrm{np}=60^{\circ} \mathrm{C} \\
\text { DSS Simulant }\end{array}$ & $\begin{array}{l}\text { Determine Impact of Temperature on } \\
\text { Hydraulics } \\
\text { Determine DP as Function of Feed and Gas } \\
\text { Rates for Comparison with Experiment } 2\end{array}$ \\
\hline 4 & $\begin{array}{l}\text { Nitrogen: } \\
\text { Feed: } \\
\text { Benzene: } \\
\text { Normal TPB, } \\
\text { No Antifoam, }\end{array}$ & $\begin{array}{l}0.2 \leq \mathrm{F}_{\mathrm{s}} \leq 1.2 \\
1-25 \mathrm{gpm} / \mathrm{ft}^{2} \\
0 \mathrm{mg} \hat{\Lambda} \\
\text { Temp }=30^{\circ} \mathrm{C} \\
\text { DSS Simulant }\end{array}$ & $\begin{array}{l}\text { Determine Maximum Flow Conditions for } \\
\text { Foaming System } \\
\text { - Comparison Points for ITP Run-In Tests }\end{array}$ \\
\hline 5 & $\begin{array}{l}\text { Nitrogen: } \\
\text { Feed: } \\
\text { Benzene: } \\
\text { Normal TPB, } \\
100 \text { ppm Antif } \\
\text { DSS Simulant } \\
\end{array}$ & $\begin{array}{l}0.2 \leq \mathrm{F}_{\mathrm{s}} \leq 1.2 \\
1-25 \mathrm{gpm} / \mathrm{ft}^{2} \\
0 \mathrm{mg} / \\
\text { Temp }=30^{\circ} \mathrm{C} \\
\text { oam }\end{array}$ & $\begin{array}{l}\text { Determine DP as Function of Feed and Gas } \\
\text { Rates for Comparison with Experiment } 2 \\
\text { Determine Maximum Flow Conditions }\end{array}$ \\
\hline Phase 2 & & & \\
\hline 6 & $\begin{array}{l}\text { Nitrogen: } \\
\text { Feed: } \\
\text { Benzene: } \\
\text { Normal TPB, } \\
0,100 \text { ppm Ar } \\
\text { DSS Simulant }\end{array}$ & $\begin{array}{l}\mathrm{F}_{\mathrm{s}}=0.5 \\
10,25 \mathrm{gpm} / \mathrm{ft}^{2} \\
150 \mathrm{mg} / \\
\text { Temp }=30^{\circ} \mathrm{C} \\
\text { atifoam }\end{array}$ & $\begin{array}{l}\text { Evaluate Stripping Efficiency With and } \\
\text { Without Antifoam for DSS } \\
\text { - Determine If Benzene Acts As Antifoam } \\
\text { - Determine Maximum Flow Conditions }\end{array}$ \\
\hline 7 & $\begin{array}{l}\text { Nitrogen: } \\
\text { Feed: } \\
\text { Benzene: } \\
\text { Normal TPB, } \\
0,100 \text { ppm Ar } \\
\text { WW Simulant }\end{array}$ & $\begin{array}{l}F_{\mathrm{s}}=0.5 \\
10,25 \mathrm{gpm} / \mathrm{ft}^{2} \\
>500 \mathrm{mg} / 1 \\
\text { Temp }=30^{\circ} \mathrm{C} \\
\text { ntifoam }\end{array}$ & $\begin{array}{l}\text { - Evaluate Stripping Efficiency With and } \\
\text { Without Antifoam for WW } \\
\text { - Determine Maximum Flow Conditions }\end{array}$ \\
\hline
\end{tabular}


WSRC-TR-93-468

Revision 0

Page 20 of 37

Table I (continued)

Phase 3

\begin{tabular}{|c|c|c|}
\hline $8 \mathrm{~A}$ & $\begin{array}{ll}\text { Nitrogen: } & \mathrm{F}_{\mathrm{s}}=0.2 \\
\text { Feed: } & 25 \mathrm{gpm} / \mathrm{ft}^{2} \\
\text { Benzene: } & 100 \mathrm{mg} / \\
\text { Normal TPB, } & \text { Temp }=30^{\circ} \mathrm{C} \\
\text { No Antifoam, } & \text { DSS Simulant }\end{array}$ & $\begin{array}{l}\text { Evaluate Stripping Efficiency At Reduced } \\
\text { Nitrogen Rates } \\
\text { Determine If Maximum DP Is Less Than } \\
40^{\prime \prime} \text { wc }\end{array}$ \\
\hline $8 B$ & $\begin{array}{ll}\text { Nitrogen: } & \mathrm{F}_{\mathrm{s}}=0.5 \\
\text { Feed: } & 25 \mathrm{gpm} / \mathrm{ft}^{2} \\
\text { Benzene: } & 200 \mathrm{mg} / \\
\text { Normal TPB, } & \text { Temp }=30^{\circ} \mathrm{C} \\
\text { No Antifoam, } & \text { DSS Simulant } \\
\end{array}$ & $\begin{array}{l}\text { Determine Impact of Benzene on DP } \\
\text { - Evaluate Stripping Efficiency for High } \\
\text { Benzene Concentration }\end{array}$ \\
\hline $8 \mathrm{C}$ & $\begin{array}{ll}\text { Nitrogen: } & \mathrm{F}_{\mathrm{s}}=0.3 \\
\text { Feed: } & 20 \mathrm{gpm} / \mathrm{ft}^{2} \\
\text { Benzene: } & 200 \mathrm{mg} / 1 \\
\text { Normal TPB, Temp }=30^{\circ} \mathrm{C} \\
\text { No Antifoam, DSS Simulant }\end{array}$ & $\begin{array}{l}\text { Evaluate Stripping Efficiency } \\
\text { Determine Impact of High Benzene on DP at } \\
\text { Reduced Flows }\end{array}$ \\
\hline $8 \mathrm{D}$ & 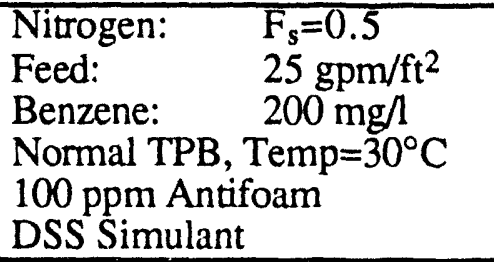 & $\begin{array}{l}\text { - Evaluate Stripping Efficiency With Antifoam } \\
\text { Present At High Benzene Concentration }\end{array}$ \\
\hline $8 \mathrm{E}$ & $\begin{array}{ll}\text { Nitrogen: } & \mathrm{F}_{\mathrm{s}}=0.5 \\
\text { Feed: } & 25 \mathrm{gpm} / \mathrm{ft}^{2} \\
\text { Benzene: } & 200 \mathrm{mg} / \mathrm{l} \\
\text { Normal TPB, Temp }=30^{\circ} \mathrm{C} \\
\text { 100 ppm Antifoam } \\
\text { DSS Simulant }\end{array}$ & - Continuation of $8 \mathrm{D}$ \\
\hline $8 \mathrm{~F}$ & $\begin{array}{ll}\text { Nitrogen: } & \mathrm{F}_{\mathrm{s}}=0.9 \\
\text { Feed: } & 25 \mathrm{gpm} / \mathrm{ft}^{2} \\
\text { Benzene: } & 200 \mathrm{mg} / 1 \\
\text { Normal TPB, Temp }=30^{\circ} \mathrm{C} & \\
100 \text { ppm Antifoam } \\
\text { DSS Simulant }\end{array}$ & $\begin{array}{l}\text { - Evaluate Stripping Efficiency With Antifoam } \\
\text { Present At High Nitrogen Rates } \\
\text { - Determine DP At Maximum WW Column } \\
\text { Design Rates }\end{array}$ \\
\hline
\end{tabular}


WSRC-TR-93-468

Revision 0

Page 21 of 37

\section{Table II. Feedstock Recipes for Pilot Scale Testing Program}

\begin{tabular}{|lcc|}
\hline Component & Amount Charged (lb) & $\begin{array}{c}\text { Resulting Solution } \\
\text { Concentration (M) }\end{array}$ \\
\hline Feedstock A1, 150 gal & 128.5 & 2.57 \\
Sodium Hydroxide & 144 & 1.35 \\
Sodium Nitrate & 2.70 & 0.015 \\
Sodium Sulfate & 33.5 & 0.39 \\
Sodium Nitrite & 1.32 & 0.010 \\
Sodium Carbonate & 46.0 & 0.45 \\
Sodium meta Aluminate & 0.32 & Not Determined \\
Potassium Hydroxide & 2.26 & Not Detected \\
Sodium TPB & Balance & - \\
DI Water & &
\end{tabular}

\section{Feedstock A2, 150 gal}

Sodium Hydroxide

Sodium Nitrate

Sodium Sulfate

Sodium Nitrite

Sodium Carbonate

Sodium meta Aluminate

Potassium Hydroxide

Sodium TPB

DI Water

\section{5 \\ 144.0 \\ 2.7 \\ 33.5 \\ 1.32 \\ 46.0 \\ 0.33 \\ 3.57}

Balance
2.57

1.35

0.015

0.39

0.010

0.45

Not Detected

0.003

Feedstock B - Trailer from Boulder Scientific

Sodium Hydroxide

Sodium Nitrate

3.07

Sodium Sulfate

1.44

Sodium Nitrite

0.018

Sodium Carbonate

0.44

Sodium meta Aluminate

Potassium Hydroxide

11.0

Sodium TPB

Benzene

42.4 (+65 lb at Koch)

0.019

0.49

DI Water

22.4

Balance

Not Detected

Excess

Excess

Feedstock C - 2100 gal Remaining of Feedstock B Diluted With DI Water Sodium TPB

Benzene

237.5

DI Water

23.2

$15000(1800 \mathrm{gal})$

Excess

Excess 
WSRC-TR-93-468

Revision 0

Page 22 of 37

Table II. (continued)

\begin{tabular}{|lcc|}
\hline \multicolumn{1}{|c|}{ Component } & Amount Charged (lb) & $\begin{array}{c}\text { Resulting Solution } \\
\text { Concentration (M) }\end{array}$ \\
\hline Feedstock D, 150 gal & 128.5 & 2.57 \\
Sodium Hydroxide & 144 & 1.35 \\
Sodium Nitrate & 2.70 & 0.015 \\
Scdium Sulfate & 33.5 & 0.39 \\
Sodium Nitrite & 1.32 & 0.010 \\
Sodium Carbonate & 46.0 & 0.45 \\
Sodium meta Aluminate & 0 & Not Detected (from impurities) \\
Potassium Hydroxide & 7.00 & Excess \\
Sodium TPB & Balance & - \\
DI Water & & \\
\hline
\end{tabular}

Table III. Impact of Packing Arrangement on Column Performance

\begin{tabular}{|c|c|c|c|c|}
\hline \multirow{2}{*}{ Experiment } & \multirow[t]{2}{*}{$\begin{array}{c}\text { Liquid } \\
\text { Rate } \\
\left.\text { (gpm/ } \mathrm{ft}^{2}\right)\end{array}$} & \multirow{2}{*}{$\underline{N i t r o g e n}_{F_{s}}$} & \multicolumn{2}{|c|}{$\begin{array}{c}\mathrm{DP} \\
\text { (in } \mathrm{H}_{2} \mathrm{O} / \mathrm{ft} \text { ) }\end{array}$} \\
\hline & & & Two Beds & One Bed \\
\hline $5 ; 8 \mathrm{D}$ & 25 & 0.5 & 0.095 & 0.09 \\
\hline $5 ; 8 \mathrm{E}$ & 25 & 0.9 & 0.55 & 0.7 \\
\hline $6 ; 8 D$ & 25 & 0.5 & 0.08 & 0.09 \\
\hline
\end{tabular}


WSRC-TR-93-468

Revision 0

Page 23 of 37

Table IV. Benzene Analysis of Samples Collected During Stripping Testing

\begin{tabular}{|c|c|c|c|c|c|}
\hline \multirow{11}{*}{$\frac{\text { Experiment }}{6}$} & \multicolumn{5}{|c|}{ Benzene Concentration (mg/1) } \\
\hline & Sample \#/Time & Feed & Mid-Column & Bottoms & Analyst \\
\hline & $6-1 / 55$ & 59.8 & & 0.5 & Koch \\
\hline & $6-2 / 85$ & 103 & 8.7 & 0.7 & Koch \\
\hline & $6-3 / 115$ & 258 & 16.2 & 1.4 & Koch \\
\hline & $6-4 / 145$ & 237 & 13.3 & 1.5 & Koch \\
\hline & $6-5 / 175$ & 170 & 3.7 & 0.4 & Koch \\
\hline & $6-6 / 205$ & 262 & 5.1 & 0.4 & Koch \\
\hline & $6-7 / 235$ & 279 & 4.1 & 0.4 & Koch \\
\hline & $6-8 / 325$ & 211 & 9.7 & 0.8 & Koch \\
\hline & $6-9 / 350$ & 247 & 15.1 & 1.4 & Koch \\
\hline 7 & $7-1 / 30$ & 558 & 12.7 & 0.8 & Koch \\
\hline & $7.2 / 60$ & 744 & 21.2 & 0.8 & Koch \\
\hline & $7-3 / 90$ & 1045 & 16.1 & 0.7 & Koch \\
\hline & $7-4 / 120$ & 1028 & 17.4 & 0.7 & Koch \\
\hline & $7-5 / 150$ & 276 & 36.4 & 1.7 & Koch \\
\hline & $7-6 / 180$ & 247 & 12.3 & 0.9 & Koch \\
\hline & $7-7 / 210$ & 781 & 6.3 & 1.5 & Koch \\
\hline & $7-8 / 240$ & 855 & 5.5 & 0.5 & Koch \\
\hline & $7-9 / 270$ & 949 & 3.3 & 0.2 & Koch \\
\hline & $7-10 / 300$ & 912 & 2.9 & 0.4 & Koch \\
\hline & $7-11 / 345$ & 966 & 37.9 & 1.8 & Koch \\
\hline & $7-12 / 375$ & 453 & 26.8 & 2.1 & Koch \\
\hline & $7-13 / 405$ & 828 & 18.0 & 2.1 & Koch \\
\hline $8 \mathrm{~A}$ & $8-1 / 65$ & 147 & - & 0.8 & Koch \\
\hline $8 \mathrm{~A}$ & $8-2 / 80$ & 129 & - & 0.5 & Koch \\
\hline $8 \mathrm{~A}$ & $8-3 / 95$ & $110(56.4)$ & - & $0.6(0.3)$ & WSRC \\
\hline $8 \mathrm{~B}$ & $8-4 / 170$ & 354 & - & 8.2 & Koch \\
\hline $8 \mathrm{~B}$ & $8-5 / 185$ & $270\left(143^{*}\right)$ & - & $2.8(1.5)$ & WSRC \\
\hline $8 \mathrm{~B}$ & $8-6 / 200$ & 300 & - & 0.9 & Koch \\
\hline $8 \mathrm{C}$ & $8-7 / 245$ & 356 & - & 5.6 & Koch \\
\hline $8 \mathrm{C}$ & $8-8 / 254$ & $300(158)$ & - & $1.5(0.8)$ & WSRC \\
\hline $8 \mathrm{C}$ & $8-9 / 272$ & 208 & - & 31.3 & Koch \\
\hline $8 \mathrm{D}$ & $8-10 / 455$ & 185 & - & 2.5 & Koch \\
\hline $8 \mathrm{D}$ & $8-11 / 470$ & $30\left(15.9^{*}\right)$ & - & $1.1(0.6)$ & WSRC \\
\hline $8 \mathrm{D}$ & $8-12 / 485$ & 83.2 & - & 3.5 & Koch \\
\hline $8 \mathrm{E}$ & $8-13 / 530$ & 219 & - & 21.2 & Koch \\
\hline $8 \mathrm{E}$ & $8-14 / 545$ & $160\left(84^{*}\right)$ & - & $22(11.7)$ & WSRC \\
\hline $8 \mathrm{E}$ & $8-15 / 560$ & 338 & - & 22.1 & Koch \\
\hline $8 \mathrm{~F}$ & $8-16 / 620$ & 116 & - & 25.4 & Koch \\
\hline $8 \mathrm{~F}$ & $8-17 / 635$ & $140(71.6)$ & - & $12\left(6.1^{*}\right)$ & WSRC \\
\hline $8 \mathrm{~F}$ & $8-18 / 650$ & 256 & - & 20.4 & Koch \\
\hline
\end{tabular}


WSRC-TR-93-468

Revision 0

Page 24 of 37

Table IV. (continued)

For WSRC analyses, actual values shown in parentheses; reported value includes correction for $10 \%$ per day benzene losses

* Sample vials received at ITP laboratory were leaking. Benzene losses assumed to be significantly greater than $10 \%$ per day. 


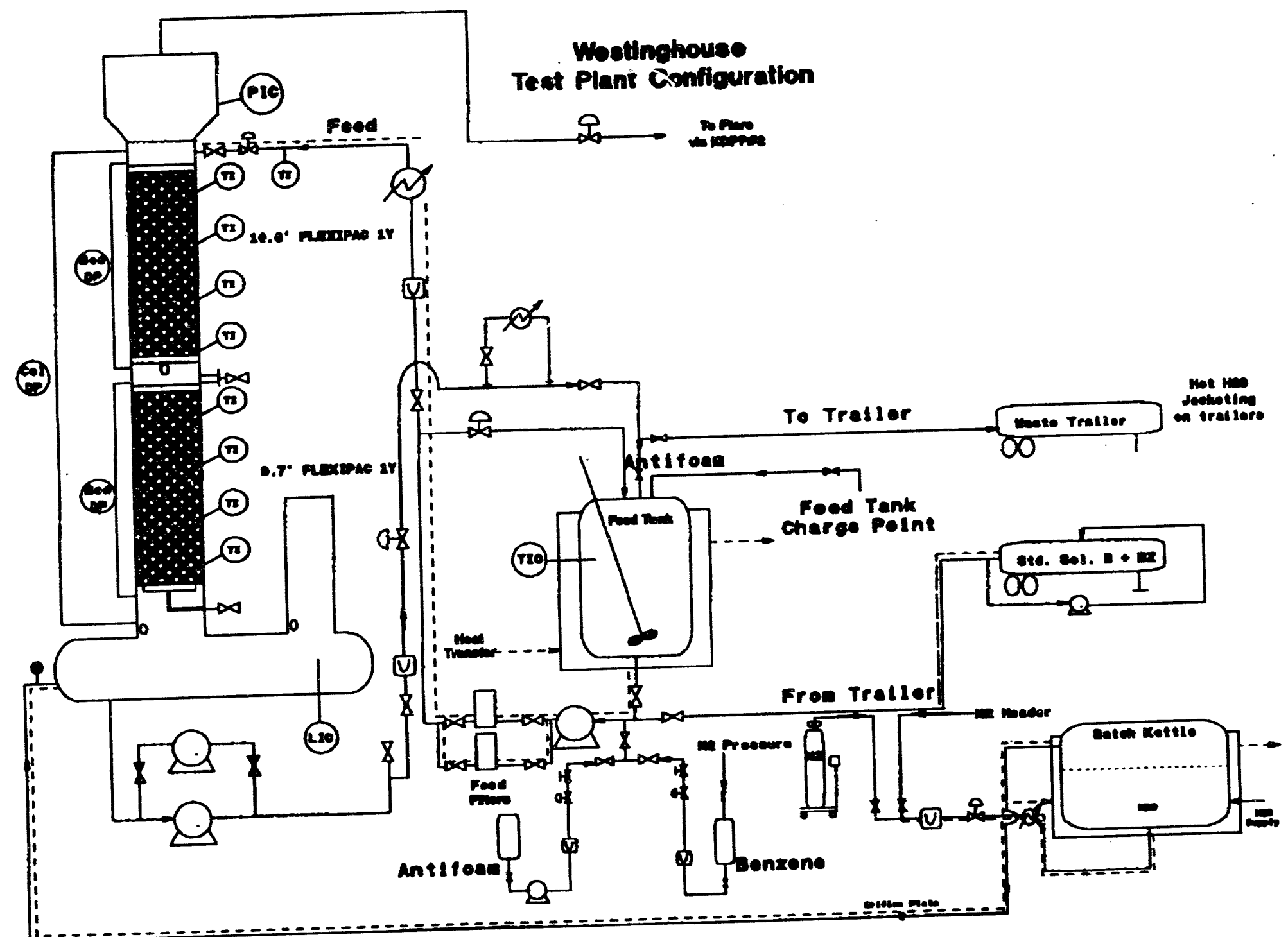

Figure 1. Schematic Diagram of Koch Pilot Scale Test Facility 
WSRC-TR-93-468

Revision 0

Page 26 of 37

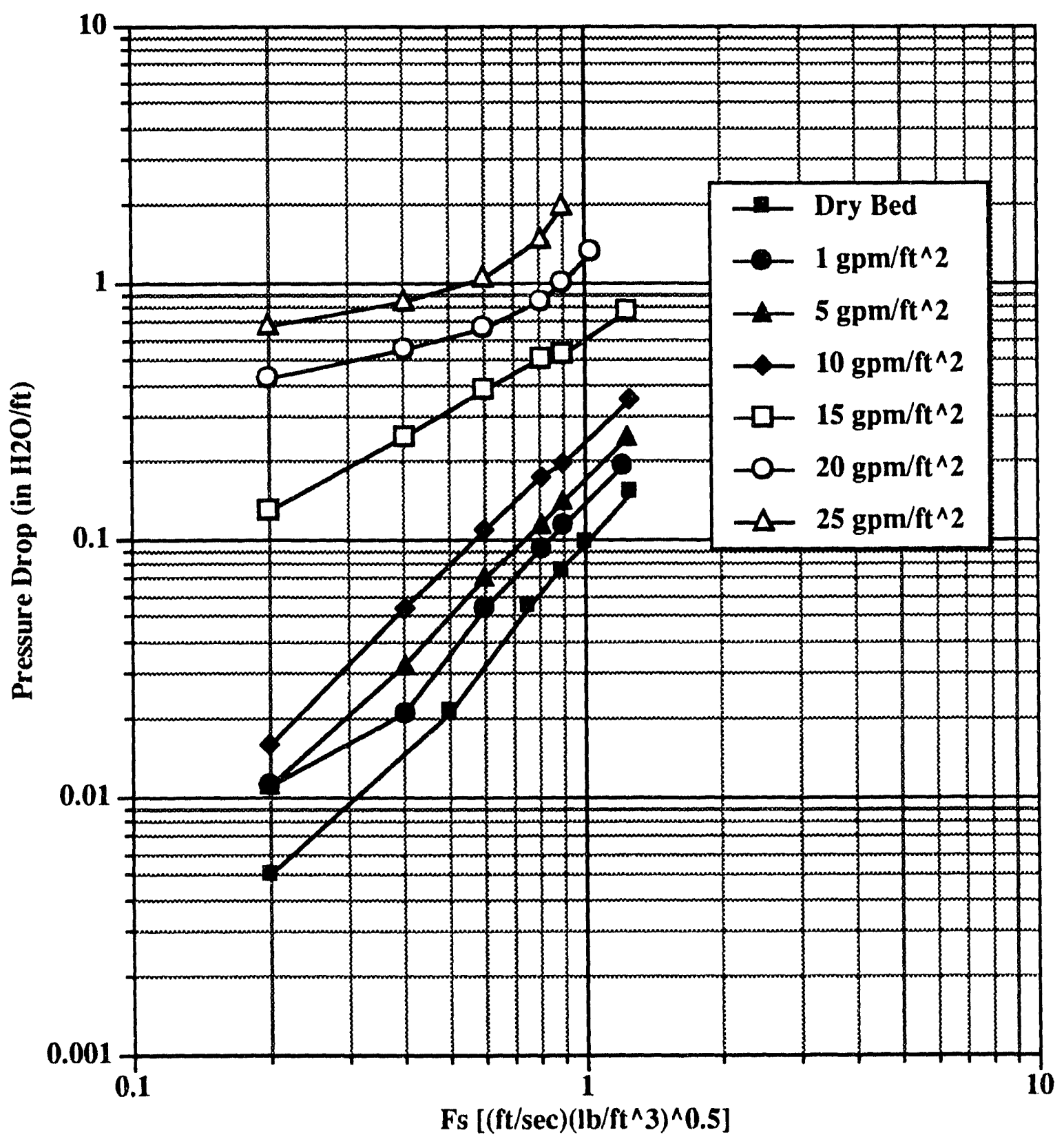

Figure 2. Differential Pressure Data for Baseline Solution 
WSRC-TR-93-468

Revision 0

Page 27 of 37

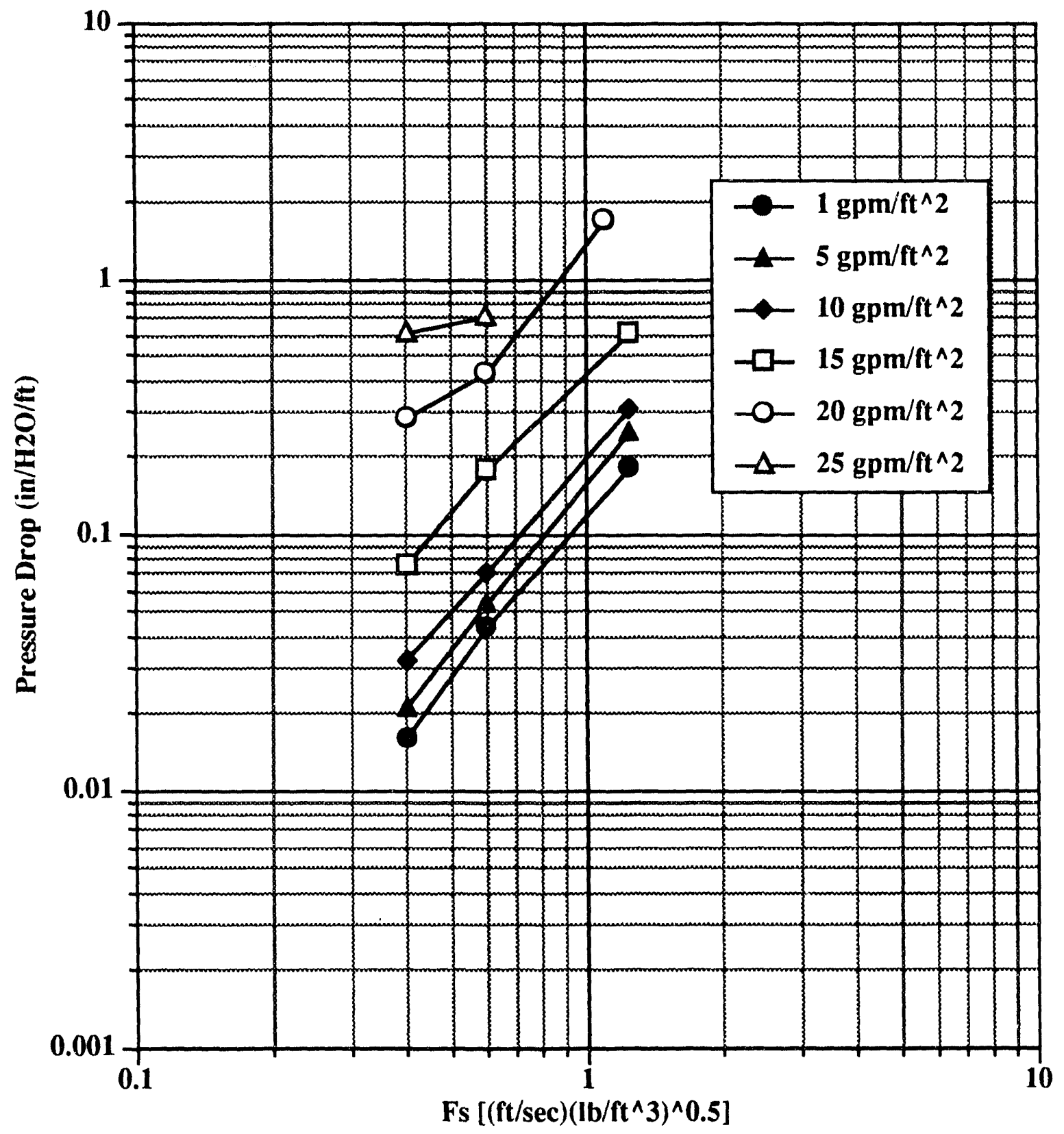

Figure 3. Differential Pressure Data for Baseline Solution at $60^{\circ} \mathrm{C}$ 
WSRC-TR-93-468

Revision 0

Page 28 of 37

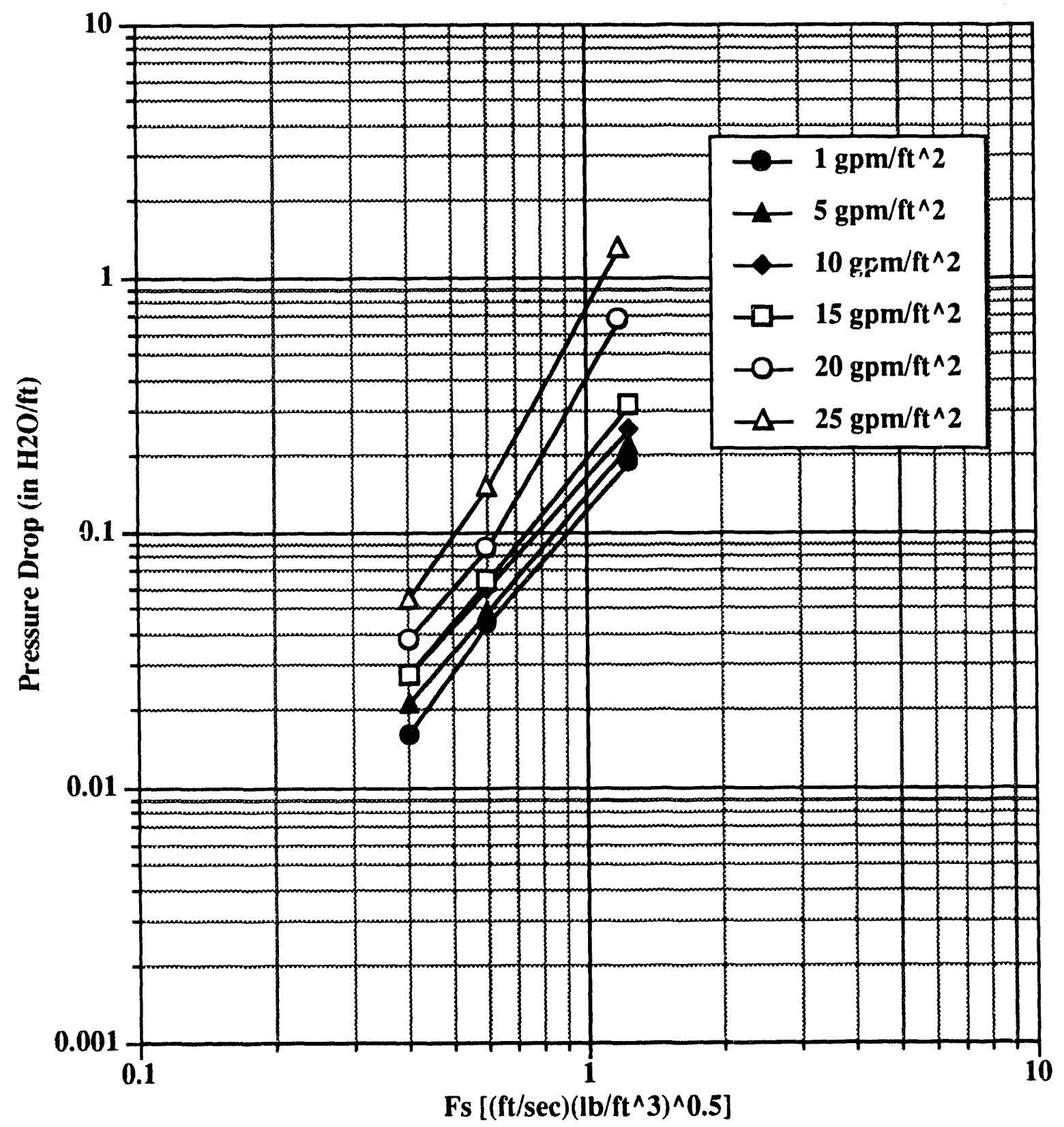

Figure 4. Differential Pressure Of Standard Solution with 100 ppm Antifoam Addition 
WSRC-TR-93-468

Revision 0

Page 29 of 37

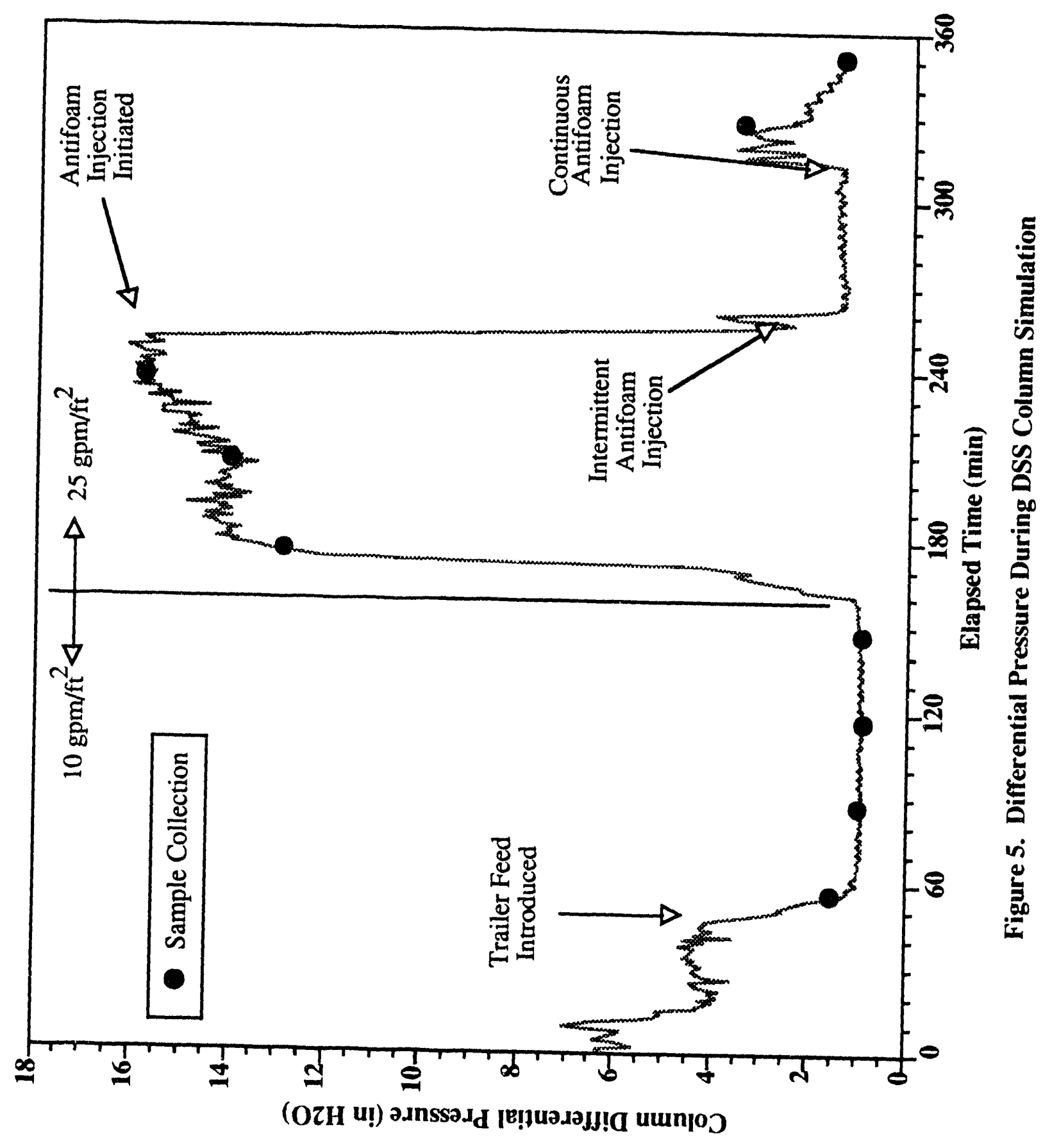


WSRC-TR-93-468

Revision 0

Page 30 of 37

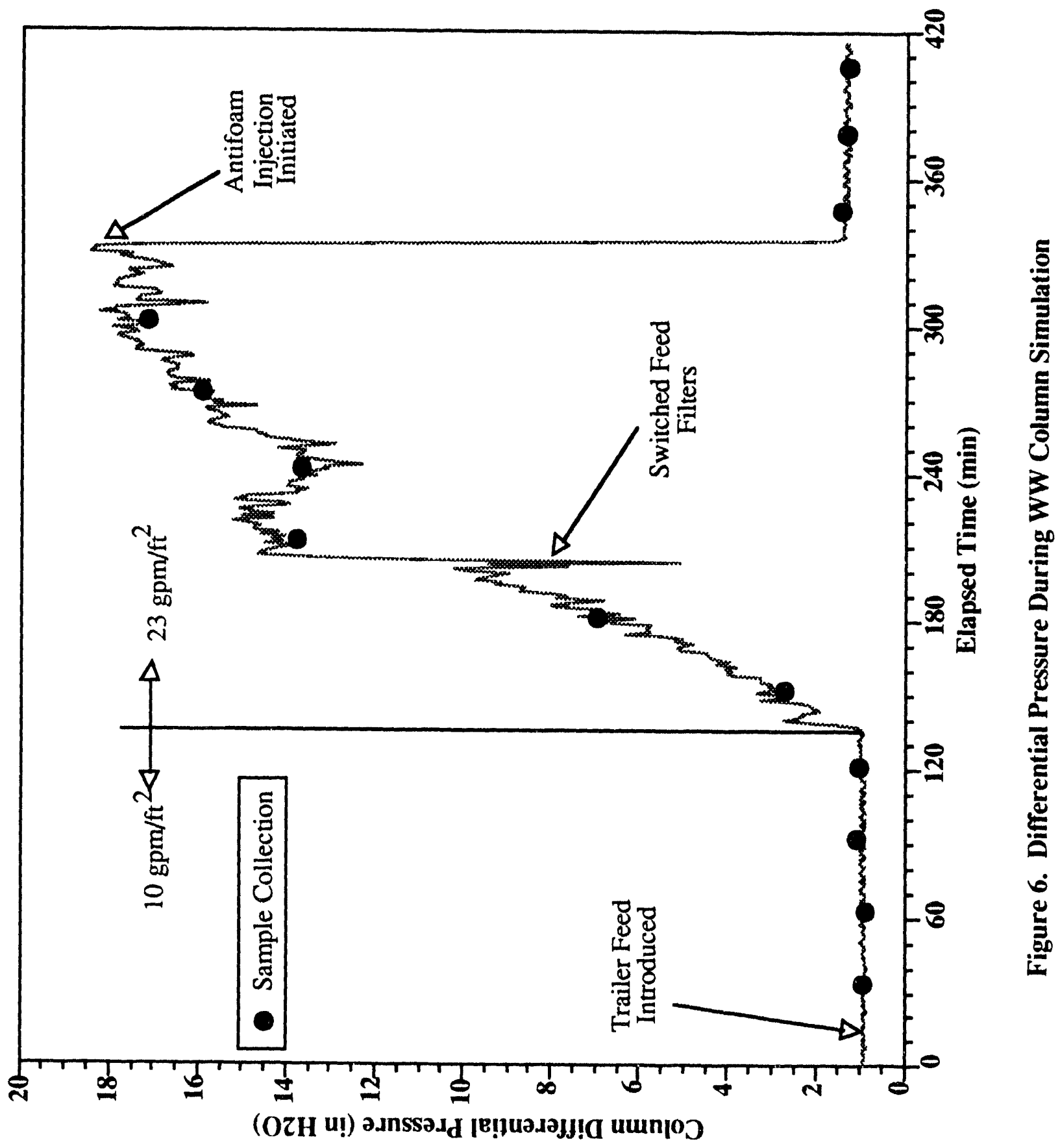


WSRC-TR-93-468

Revision 0

Page 31 of 37

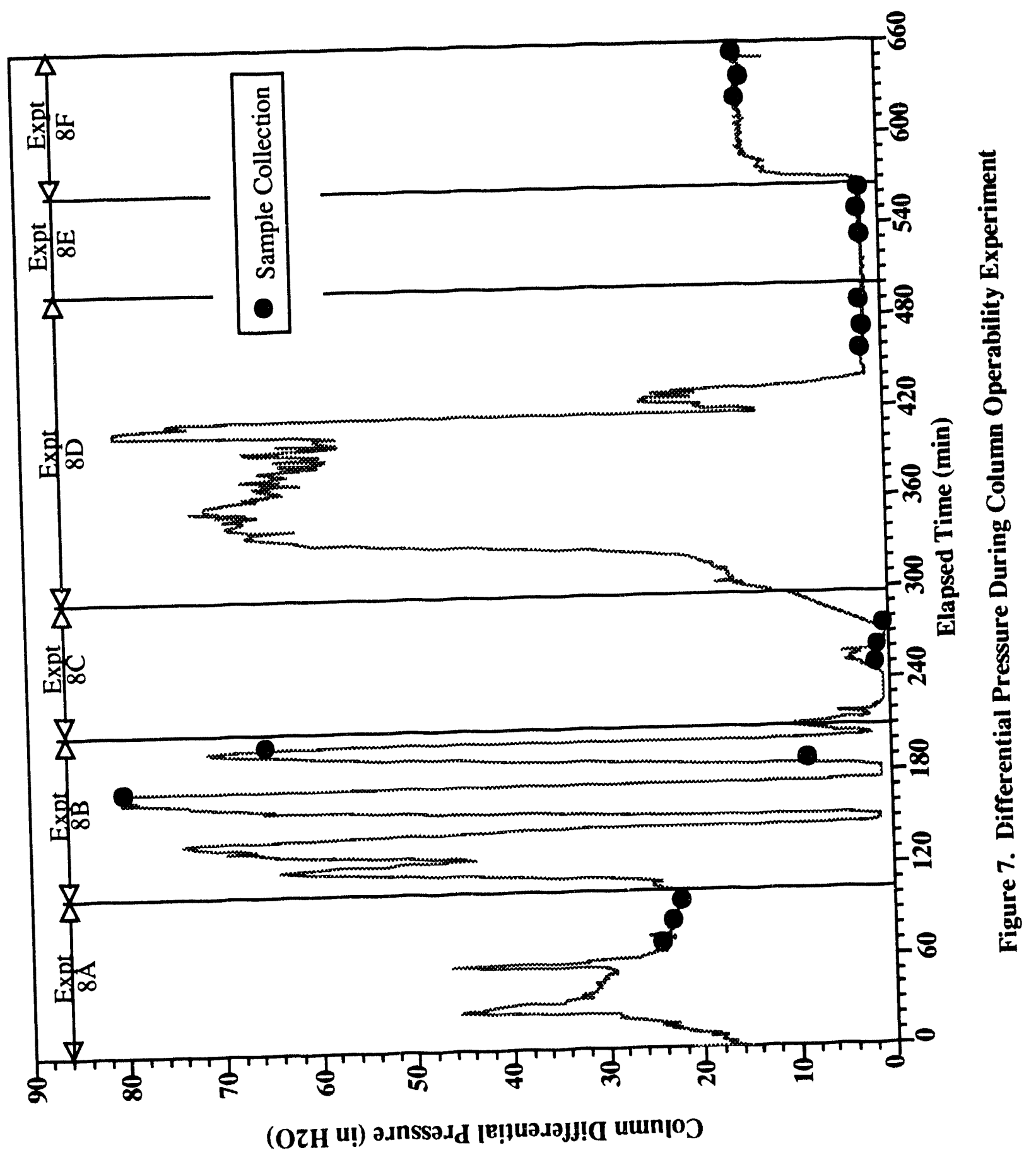


WSRC-TR-93-468

Revision 0

Page 32 of 37

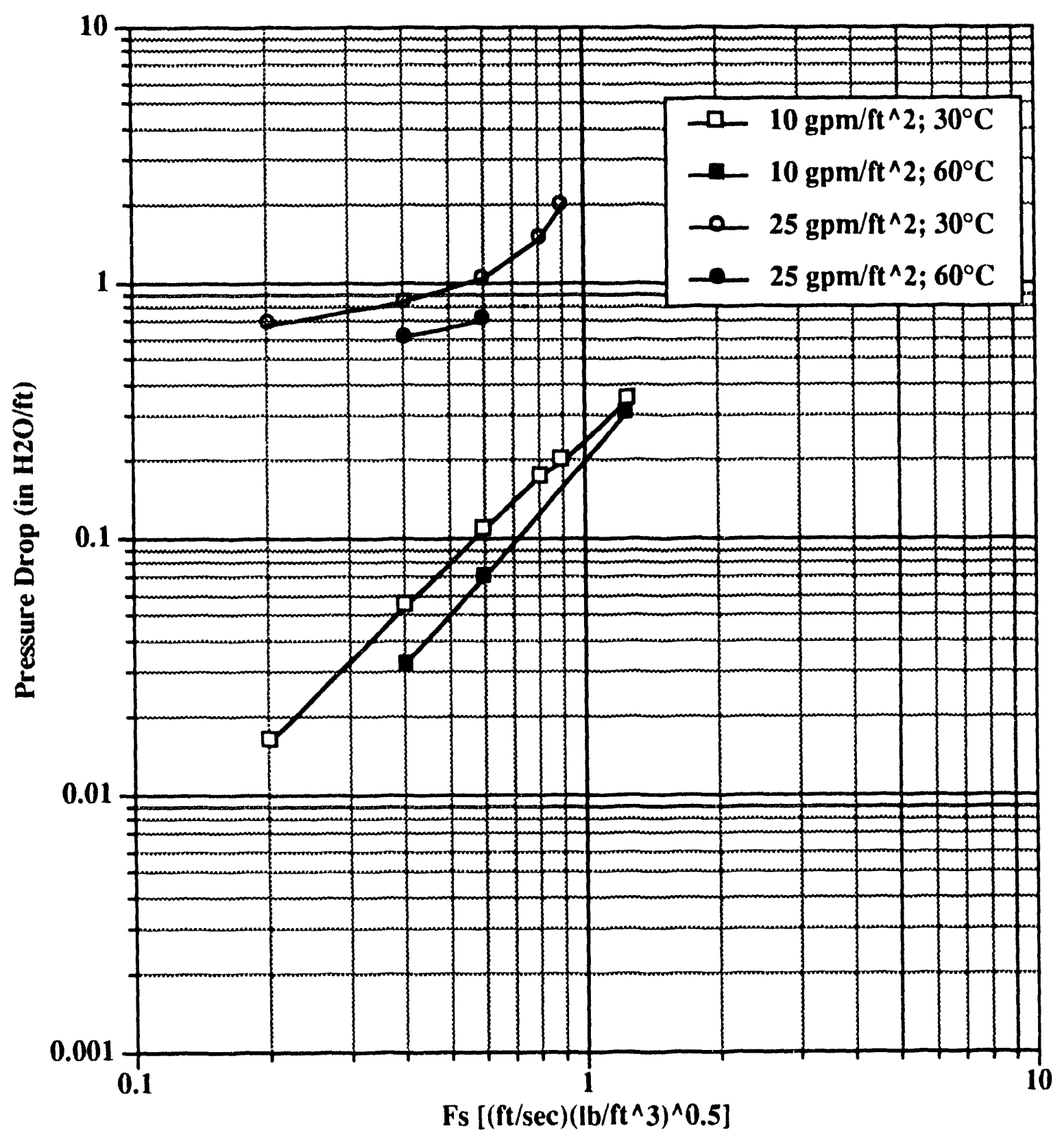

Figure 8. Impact of Temperature on Column Differential Pressure 
WSRC-TR-93-468

Revision 0

Page 33 of 37

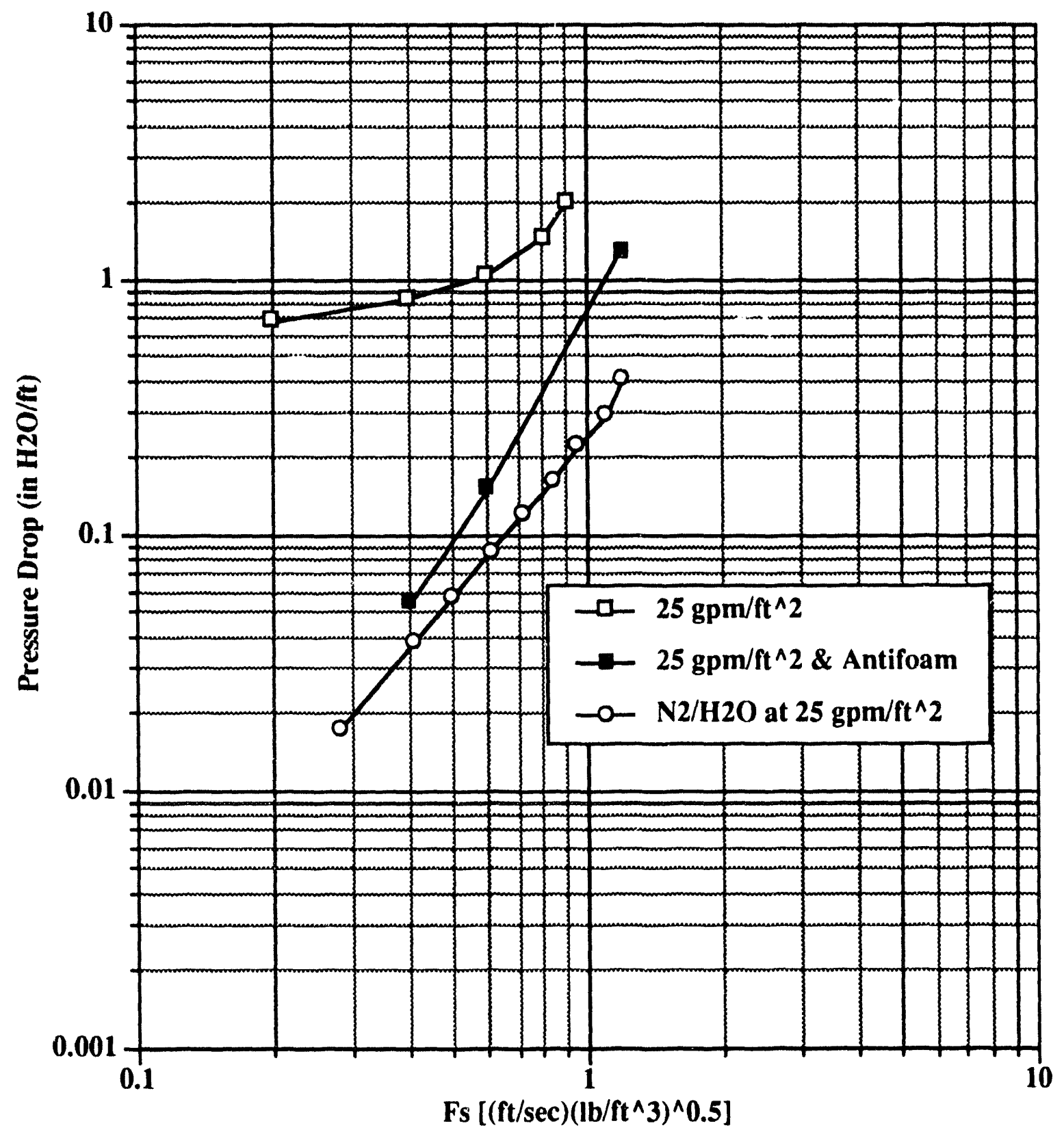

Figure 9. Impact of 100 ppm Antifoam Addition on Column Differential Pressure 
WSRC-TR-93-468

Revision 0

Page 34 of 37

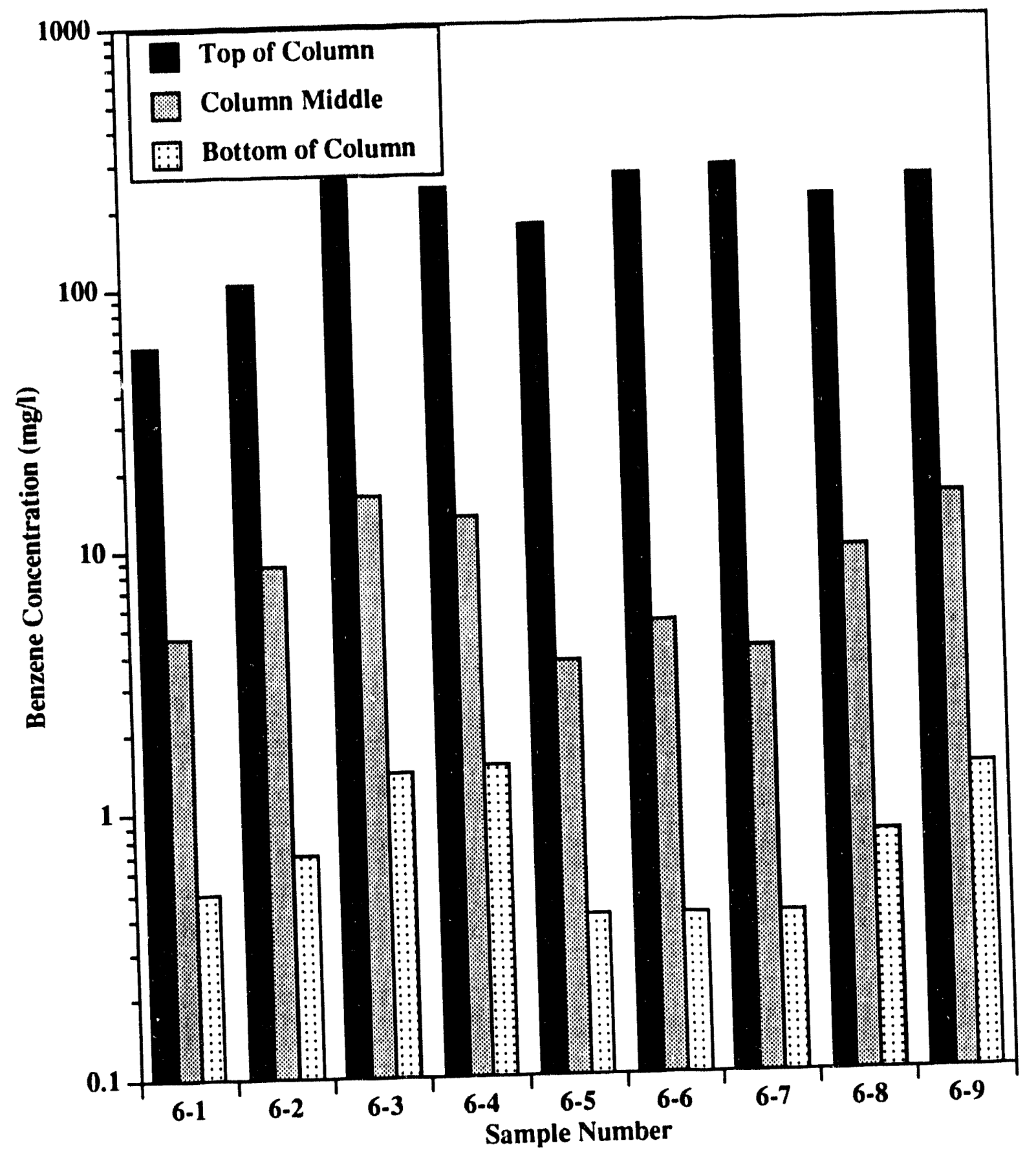

Figure 10. Benzene Removal During DSS Column Simulation 
WSRC-TR-93-468

Revision ()

Page 35 of 37

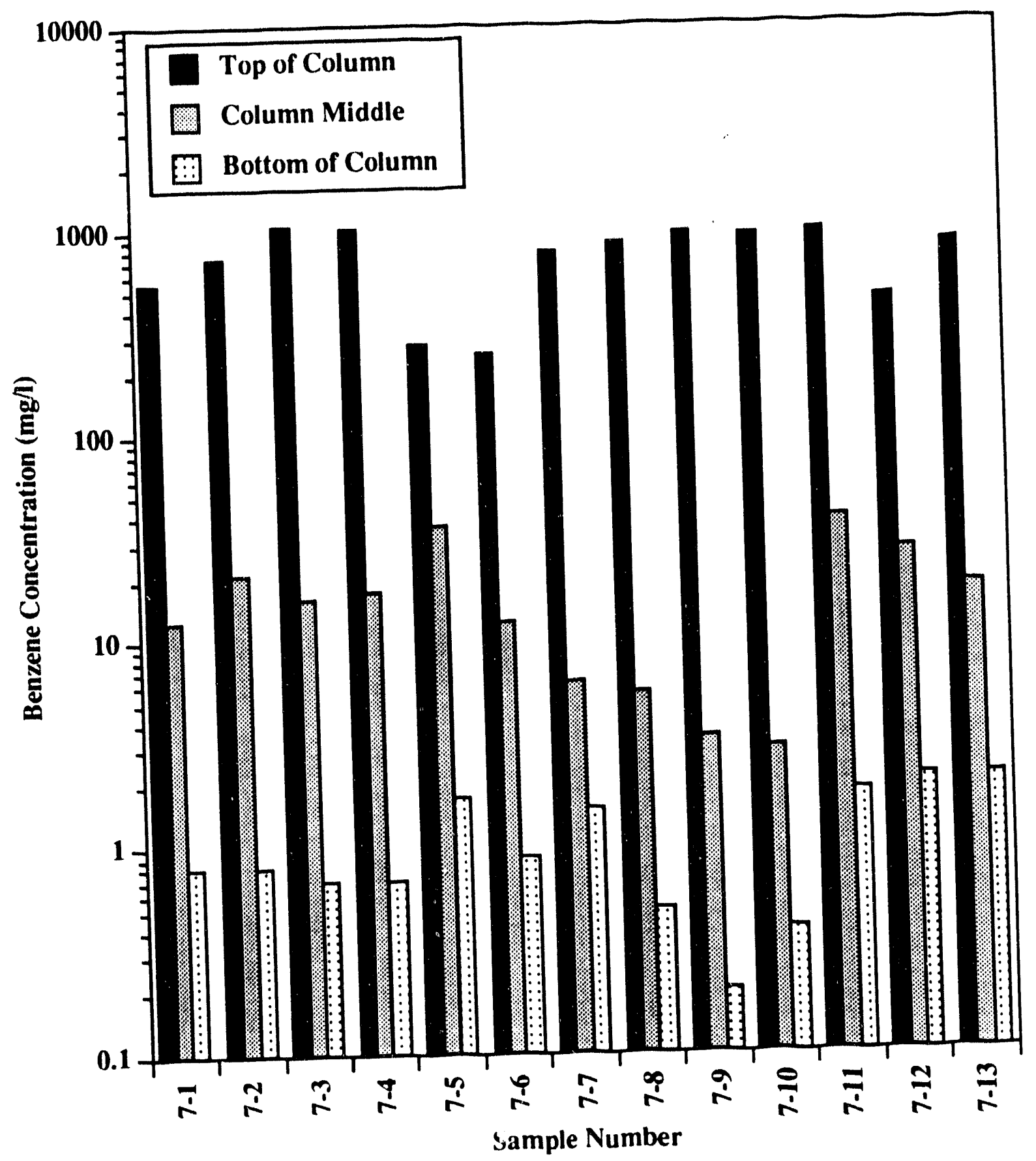

Figure 11. Benzene Removal During WW Column Simulation 
WSRC-TR-93-468

Revision 0

Page 36 of 37

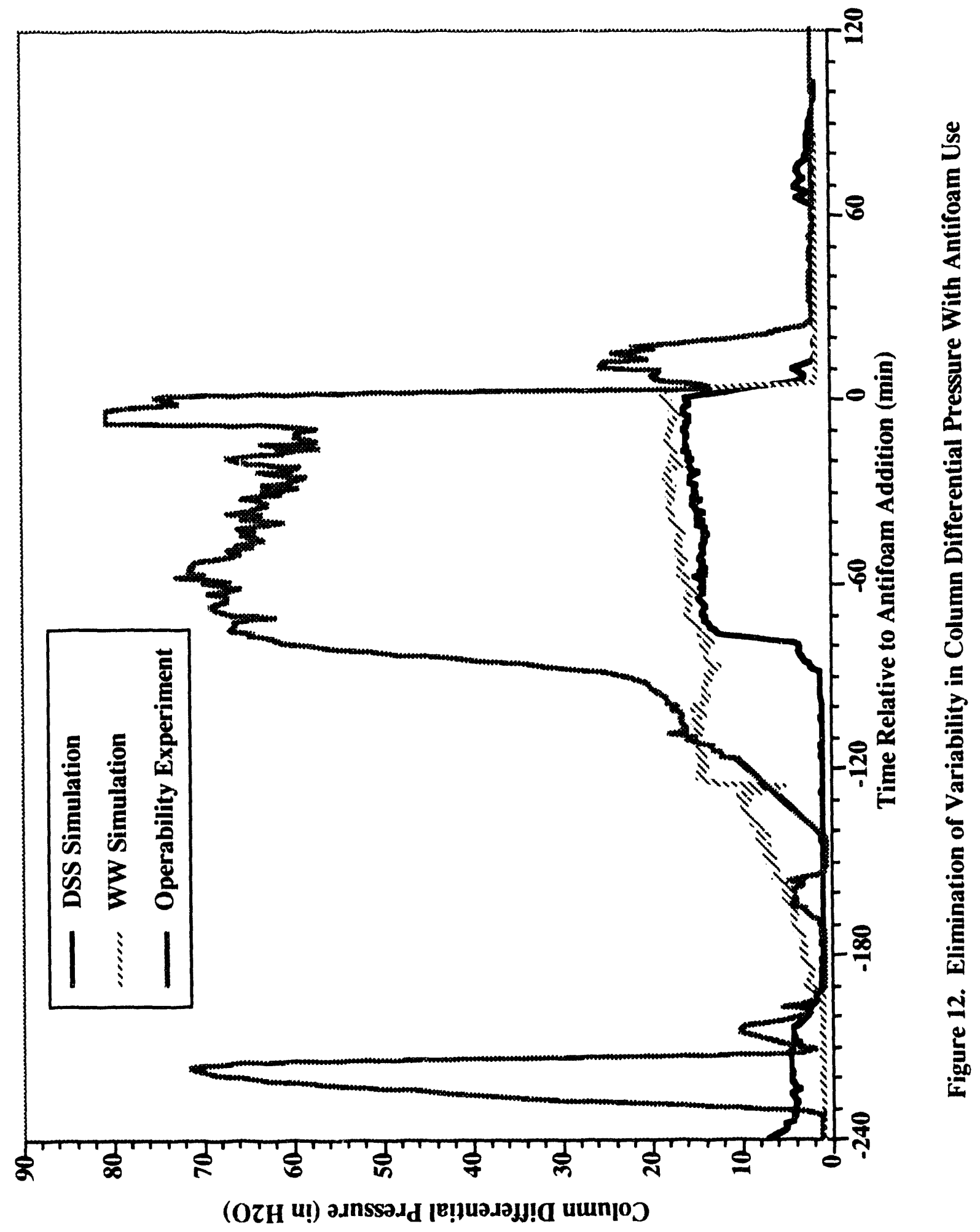




\section{Distribution List}

G. K. Georgeton, 703-H

T. P. Gaughan, $241-152 \mathrm{H}$

D. F. Brown, 703-H

J. E. Marra, 703-H

T. M. Monahon, 703-H

V. G. Dickert, 703-H

S. D. Fink, 773-A

J. F. McGlynn, 773-A

M. J. Barnes, 773-A

W. L. Tamosaitis, 773-A

M. C. Chandler, 703-H

D. D. Walker, 773-A

C. L. Peckinpaugh, 719-4A

A. B. Scott, 719-4A

C. J. Baker, $704-56 \mathrm{H}$

R. F. Swingle, 773-A

L. F. Landon, 704-T

L. M. Lee, 704-T

HLWE Files, 703-H Code 301.6
G. A. Taylor, 241-152H

R. A. Jacobs, 704-T

F. G. Smith, 704-T

B. G. Croley, 241-120H

G. T. Wright, 703-H

F. F. Cadek, 719-4A

J. N. Brooke, 241-120H

J. P. Wood, 241-119H

W. B. Van Pelt, 241-152H

G. Cauthen, 241-120H

M. L. Melton, 241-154H

H. Handfinger, $704-56 \mathrm{H}$

R. K. Roosa, 241-121H

L. O. Dworjanyn, 779-2A

R. C. Fowler, 241-152H

E. R. Ennis, 241-120H

M. Baich, 704-T 

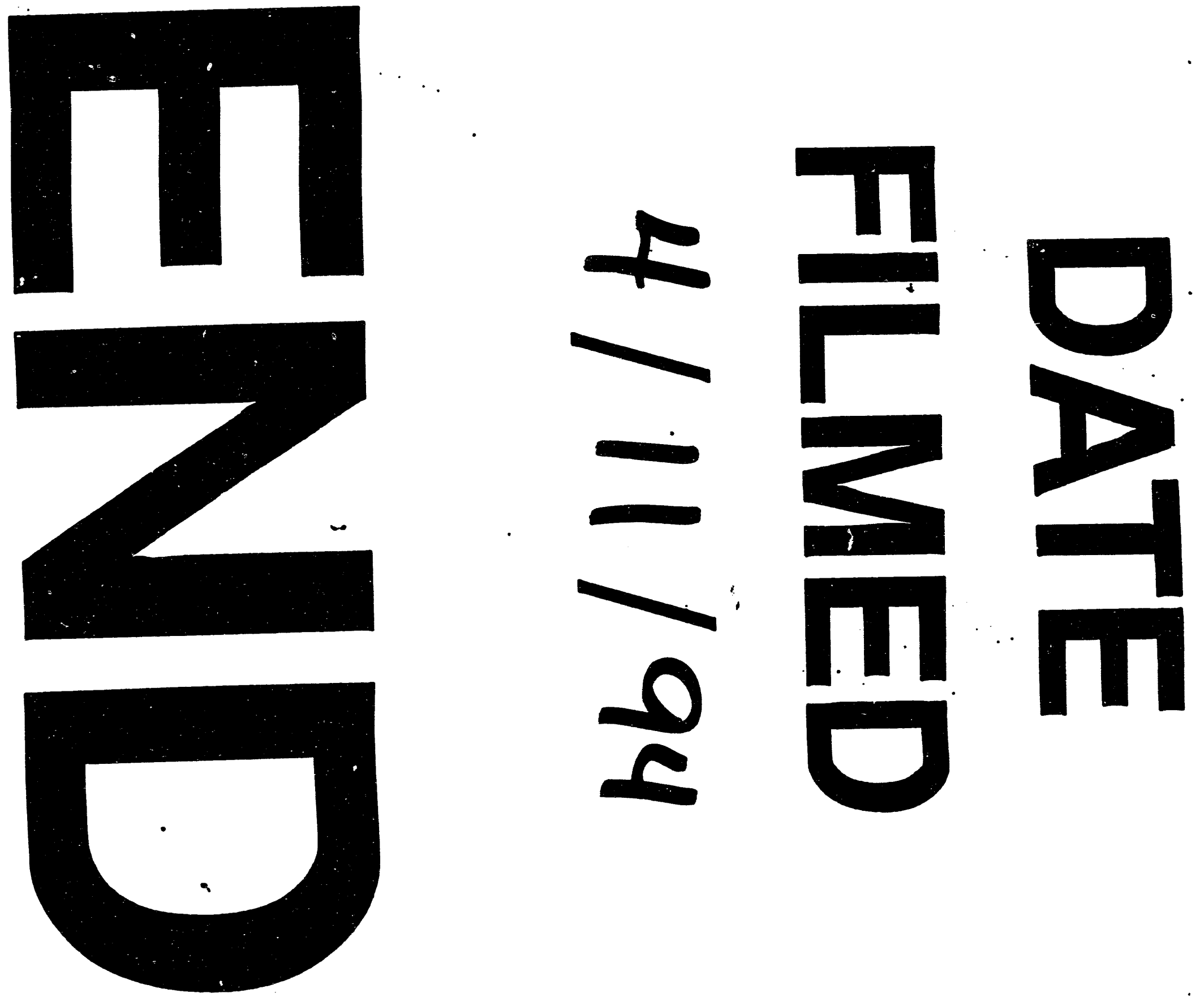
